\title{
Methodological proposal for the application of Hilbert spaces to integrated watershed management
}

\author{
María Antonina Galván Fernández ${ }^{1}$ \\ Ángel Bustamante González ${ }^{2 *}$ \\ Juan José Ambriz García ${ }^{3}$ \\ Mario Roberto Martínez Menes ${ }^{4}$
}

\begin{abstract}
The current watershed management concept is ambivalent. On the one hand, it was generated as a proposal for a systemic vision of a territory, the watershed, and it addresses complex development issues in that territory. On the other hand, the most widespread application of the concept has been reductionist in nature, since it focuses on one or some aspects of the watershed components and their relationships. Recently, the adjective integrated was added to the term watershed management, which reflects the concern to apply a holistic and systemic vision in the interventions of the physical, biological, social and economic subsystems of the watershed. However, the use of the adjective has been more conceptual than pragmatic, and there has been a lack of discussion about its implications and the challenges associated with its operationalization. This paper proposes the application of Hilbert spaces as a methodological alternative to support the planning and monitoring of watershed management intervention proposals. Hilbert spaces, which have been used in other disciplines, are considered to be an option to support the analysis and management of the watershed as a complex system.
\end{abstract}

Keywords: Complex, watershed, management, system.

\section{Propuesta metodológica de aplicación de los espacios de Hilbert al manejo integral de cuencas}

\section{Resumen}

El concepto de manejo de cuencas actual es ambivalente. Por un lado, se generó como una propuesta de visión sistémica de un territorio, la cuenca, y aborda temas de desarrollo de ese territorio que son complejos. Por otro lado, la aplicación más generalizada del concepto ha sido de carácter reduccionista, ya que centra su atención en uno o algunos aspectos de los componentes y relaciones de la cuenca. Recientemente, se ha adicionado al término manejo de cuencas el adjetivo integral, lo que refleja la preocupación de aplicar una visión holista y sistémica en las intervenciones de los subsistemas físicos, biológicos, sociales y económicos de la cuenca. Sin embargo, el uso del adjetivo ha sido más conceptual que pragmático, y se ha adolecido de una reflexión sobre sus implicaciones y los retos asociados a su operacionalización. En el presente trabajo se propone la aplicación de los espacios de Hilbert como una alternativa metodológica que soporte la planificación y seguimiento de propuestas de intervención de manejo de cuencas. Se considera que los espacios de Hilbert, que han sido utilizados en otras disciplinas, son una opción para fundamentar el análisis y la gestión de la cuenca como un sistema complejo.

Palabras clave: Complejo, cuenca, gestión, sistema.

'Colegio de Postgraduados -Campus Puebla. Postgrado en Estrategias para el Desarrollo Agrícola Regional, km 125.5 Carretera Federal México-Puebla, Santiago Momoxpan, C.P.72760, San Pedro Cholula, Pue.

${ }^{2}$ Colegio de Postgraduados-Campus Puebla. km 125.5 Carretera Federal México-Puebla, Santiago Momoxpan, C.P. 72760, San Pedro Cholula, Pue.

${ }^{3}$ Universidad Autónoma Metropolitana Iztapalapa, División de Ciencias Básicas e Ingeniería. México.

4Colegio de Postgraduados-Campus Montecillo. km 36.5, Carretera México-Texcoco, Montecillo Texcoco, Estado de México.

*Corresponding author: angelb@colpos.mx

Received: November 4, 2017.

Accepted: November 28, 2019. 


\section{Introduction}

Watershed management is a discipline whose initial objective was to generate proposals for integrated intervention in these territories through a complex development system capable of coordinating all aspects of public management. Specific actions were considered, such as flood control, river navigation for the transport of goods, distribution of electricity, forestry and agricultural development, and soil recovery for mass agricultural production. Although there were successful economic and social results, these actions also generated environmental problems, such as dam silting and soil compaction and salinization (Corominas \& Franquesa, 2015).

Watershed management has gone through several development stages. It began with agricultural production and research on soil loss and runoff assessment with conceptual-empirical models of the phenomenon. Once the phenomenon was understood, efforts were oriented towards modeling the response of the soil (fertility) to production processes (plot level) and later on to estimating the response at the ecosystem level to land-use changes. Afterwards, Geographic Information Systems (GIS), advanced computation, and rainfall and soil drag models validated with observational data were incorporated. These stages are characterized by being loaded with technology and mathematical applications. Lately, in a process of balance with the hard sciences, the orientation has shifted to the humanistic phase, which is the administrative one. This envisions the need to integrate the economic and social aspects of the exploitation of natural resources, although at the beginning they are considered to be concepts that are not very applicable, given the high variability of environmental responses. This in turn forms the management phase, through the socalled Systemic School of Administration. Finally, strategic planning became the tool that allowed the administration of natural resources to be addressed.

Although watershed management has adapted to different paradigms, with the intention of responding to specific questions, the negative impacts resulting from the exploitation of natural resources continue. To meet the challenge of sustainable development, it is necessary to rethink watershed management. Munasinghe and Shearer (1995) state that the current

\section{Introducción}

El manejo de cuencas es una disciplina cuyo objetivo inicial fue generar propuestas de intervención integral de los territorios, mediante un complejo sistema de desarrollo capaz de coordinar todos los aspectos de la gestión pública. Se consideraron acciones específicas como el control de inundaciones, navegación fluvial para el transporte de mercancías, distribución de la energía eléctrica, desarrollo forestal y agrícola y, la recuperación de suelos para la masificación de la producción agrícola. Si bien se tuvieron resultados económicos y sociales exitosos, se generaron problemas ambientales derivados de esas acciones, como el azolvamiento en presas y la compactación y salinización de suelos (Corominas \& Franquesa, 2015).

El desarrollo del manejo de cuencas ha tenido diferentes etapas. Se inicia con la producción agrícola y la investigación sobre pérdida de suelos y evaluación de escurrimientos con modelos conceptualesempíricos del fenómeno. Una vez superada la comprensión del fenómeno, se orientó al modelaje de la respuesta del suelo (fertilidad) ante los procesos de producción (nivel parcela) y, en un segundo tiempo, a estimar la respuesta a nivel ecosistema de los cambios de uso del suelo. Después, se incorporan los Sistemas de Información Geográfica (SIG), cómputo avanzado $y$, modelos de lluvia y de arrastre de suelos validados con datos observacionales. Estas etapas se caracterizan por estar cargadas de tecnología y aplicaciones matemáticas. Últimamente, en un proceso de equilibrio con las ciencias duras, se da paso a la fase humanística: la administrativa. En esta se vislumbra la necesidad de integrar los aspectos económicos y sociales de la explotación de los recursos naturales, aunque al inicio se consideran conceptos poco aplicables, dada la alta variabilidad de las respuestas del medio ambiente. Esto a su vez forma la fase de gestión, a través de la llamada Escuela Sistémica de la Administración. Finalmente, la planeación estratégica vino a ser la herramienta que permitió abordar la administración de los recursos naturales.

A pesar de que el manejo de cuencas se ha adaptado a diferentes paradigmas, con la intensión de responder a cuestionamientos específicos, los impactos negativos derivados de la explotación de los recursos naturales continúan. Para encarar el reto del desarrollo sustentable, es necesario replantear 
analytical tools must be modified in order to be useful in the face of the new development paradigm.

On the other hand, the problem in Integrated Watershed Management is addressed by more than one area of knowledge, giving it a complex nature, which requires a significant change in the way problems are perceived, defined and solved. This change must move away from the perspective of closed systems, where a simple definition, fixed concepts and ultimate solutions are proposed, to refocus on open systems, where problems and solutions are multidimensional, dynamic and evolutionary in time (Ratcliffe \& Stubbs, 1996).

In order to achieve this, it is necessary to integrate information from a wide range of disciplines to understand, analyze, synthesize and propose solutions to each of the factors that make up the watershed, both in terms of complexity and extension. Therefore, the task of current watershed management is to find a way to integrate all the dimensions and analyses provided by the disciplines to produce the essential scientific, socioeconomic and philosophical information needed to develop practical and effective strategies and policies. The final element of forcing is the evaluation of such strategies, where performance in terms of sustainability is becoming a critical parameter of competitiveness, survival and coexistence among societies. This is why indicators are increasingly being constructed to reflect the efficiency of interventions.

Here we present the development of $a$ methodological proposal to support, from a theoretical-conceptual and operational perspective, the management of a watershed as a complex system. The proposal is logical-mathematical in nature and is based on the application of Hilbert spaces, which have been applied in other disciplines, but not to development or natural resource management issues.

\section{Contextual framework}

Land-use change increased from the 1970s onwards, coupled with population growth and thus increased demand for food, housing and industry for the production of satisfiers. Humanity's challenge is to undertake sustainable actions that maintain the standard of living and development of today's el manejo de cuencas. Munasinghe y Shearer (1995) mencionan que las herramientas analíticas actuales deben ser modificadas para ser útiles frente al nuevo paradigma del desarrollo.

Por otro lado, la problemática en el Manejo Integral de Cuencas se aborda por más de un área de conocimiento, dándole una naturaleza compleja, que requiere de un cambio significativo en la forma en que los problemas son percibidos, definidos y resueltos. Este cambio debe alejarse de la perspectiva de sistemas cerrados, donde se plantea una definición simple, conceptos fijos y soluciones últimas, para reenfocarse en sistemas abiertos, donde los problemas y las soluciones sean multidimensionales, dinámicas y evolutivas en tiempo (Ratcliffe \& Stubbs, 1996).

Para lograr lo anterior, se requiere de la integración de información de un rango amplio de disciplinas que permita comprender, analizar, sintetizar y proponer soluciones a cada uno de los factores que componen la cuenca, tanto en complejidad como en extensión. Entonces, la tarea del actual manejo de cuencas es encontrar la forma de integrar todas las dimensiones y análisis aportados por las disciplinas, para producir la información esencial necesaria en lo científico, socioeconómico y filosófico que permitan desarrollar estrategias y políticas prácticas y efectivas. Como elemento final de forzamiento se tiene la evaluación de dichas estrategias, donde el desempeño en términos de sustentabilidad se está convirtiendo en un parámetro crítico de competitividad, supervivencia y convivencia entre las sociedades. Es así como cada vez más se recurre a la construcción de indicadores que reflejen la eficiencia de las intervenciones.

Aquí se presenta el desarrollo de una propuesta metodológica para fundamentar, desde la perspectiva teórica-conceptual y operativa, el manejo de una cuenca como un sistema complejo. La propuesta es de carácter lógico-matemático y se basa en la aplicación de los espacios de Hilbert, los cuales se han aplicado en otras disciplinas, pero no a temas de desarrollo o de manejo de recursos naturales.

\section{Marco contextual}

El cambio de uso del suelo se incrementó a partir de los años 70, aparejado al crecimiento poblacional y con ello, al incremento de la demanda de alimentos, 
communities, but that are also capable of meeting the needs of future generations. Until now this question has been addressed on a global scale such as the sustainability of planet Earth, which, however, depends on the actions implemented at lower aggregation levels. Under this new paradigm, welfare objectives should include local productive systems, promoting their articulation with production and consumption initiatives, but also the assimilation of the residual products of such actions.

The increase in extreme hydrological events, such as major floods, and their damage to crops and infrastructure along with the loss of human life have been largely associated with land-use change (LULUCF, 2009). As mountain settlements have increasingly been located at higher risk sites, such as river plains, lagoon beds and coastal areas, there are virtually no areas in the world where there are no human populations that will not eventually be affected.

The purpose of integrated resource management is to determine the natural logical uses of each environment that makes up ecosystems in order to establish plans aimed at a) the appropriate exploitation of resources, $b$ ) the buffering of urbanization processes (fragmentation of the space-vegetation, waste absorption) and c) the eventual recovery of natural and social capital. Watershed management has established relationships between land, vegetation and climate; it has proposed the modeling and prediction of runoff. This has allowed it to define management plans. But these plans are oriented to medium- to long-term interventions. Numerical modeling, one of the most widely used tools, has become stagnant in static prospecting, mainly because all these approaches have been made on the basis of disciplinary and reductionist analyses. The reductionist approach leads to particular solutions, which depend on the paradigm that prevails at the historical moment of decision making.

However, although watershed management has adapted to different historical paradigms, with the intention of responding to specific questions, the negative impacts resulting from the exploitation of natural resources continue. This paper considers that the reductionist approach has been overtaken vivienda e industria para la producción de satisfactores. La humanidad tiene como reto hacer sustentables las acciones que mantengan el nivel de vida y de desarrollo de las comunidades actuales, pero que sean capaces de satisfacer también las necesidades de las generaciones futuras. Hasta hoy esta pregunta ha sido abordada a escala global como la sustentabilidad del planeta Tierra, que, sin embargo, depende de las acciones implementadas en niveles de menor agregación. Bajo este nuevo paradigma, los objetivos de bienestar deben incluir a los sistemas productivos locales, promoviendo su articulación con las iniciativas de producción y consumo, pero también la asimilación de los productos residuales de dichas acciones.

El aumento de eventos hidrológicos extremos, como las avenidas de gran magnitud, y sus daños en cultivos, infraestructura y pérdida de vidas humanas se ha asociado en gran parte al cambio del uso del suelo (LULUCF, 2009). Debido a que los poblados de zonas montañosas se han ido emplazando cada vez más a sitios con mayor riesgo, como las vegas de ríos, lechos lagunares y zonas costeras, prácticamente ya no existen zonas del mundo donde no existan poblaciones humanas que no sean afectadas eventualmente.

El manejo integral de los recursos tiene la finalidad de determinar las vocaciones naturales de cada entorno que componen a los ecosistemas para establecer planes dirigidos a) la explotación adecuada de los recursos, b) el amortiguamiento de los procesos de urbanización (fragmentación del espacio-vegetación, absorción de residuos) y c) la recuperación eventual del capital natural y social. El manejo de cuencas ha establecido relaciones entre el terreno, la vegetación y el clima; ha planteado el modelado y la predicción de los escurrimientos. Esto le ha permitido definir planes de manejo. Pero estos planes se orientan a intervenciones a medianolargo plazo. La modelación numérica, una de las herramientas más utilizadas, se ha estancado en la prospección estática, derivado principalmente de que todos estos acercamientos se han hecho a partir de análisis disciplinarios y reduccionistas. El enfoque reduccionista lleva a soluciones particulares, que dependen del paradigma que prevalece en el momento histórico de la toma de decisión.

Sin embargo, a pesar de que el manejo de cuencas se ha adaptado a diferentes paradigmas históricos, 
by environmental problems, with the systemic approach being a more appropriate paradigm, although it has so far been more descriptive than applied, because it requires knowledge and tools from areas of knowledge outside watershed management. The fundamental proposal is to move from a reductionist system to a holistic approach in watershed management, through the application of the theoretical concepts of Hilbert spaces. Unlike proposals that have addressed the issue from a conceptual rather than operational perspective, such as Garcés (2011), the methodological proposal presented is intended for application as a planning and decision-making tool.

\section{Theoretical framework}

\section{Reductionist system}

There is a great diversity of approaches to address the relationship between reality and the sciences that characterize, normalize and explain it. Any approach to these relationships is based on philosophical assumptions. The philosophical basis of any science establishes the characteristics of the field of knowledge, developed from a research process defined as first-order relationships. In contrast, metaphysics establishes the analysis of the most general characteristics of reality as second-order relationships (Zela, 2013).

Science is defined as the empirical study of the order that regulates the relationships between natural subsystems, philosophically defined as scientific materialism. It seeks to generate knowledge from verifiable bases in the perfectly limited material-physical space (Universe), defined as empirical sensory data (variables) that are contained in homogeneous systems (sets), and related through logical-reductionist structures that explain phenomena in a simplistic way (functions). Figure 1 shows the reductionist structure of reality (Russell, Stoeger, \& Coyne, 2004; Luna, 2012).

The conditioning factor of this structure that gives rise to the axiomatic reductionist approach is that the set is continuous and, therefore, the relationship between sets, defined as a cause-effect relationship, is also continuous, and consequently derivable. con la intensión de responder a cuestionamientos específicos, los impactos negativos derivados de la explotación de los recursos naturales continúan. En este documento se considera que el enfoque reduccionista ha sido rebasado por la problemática ambiental, siendo el enfoque sistémico un paradigma más adecuado, aunque lo sistémico ha sido hasta ahora más descriptivo que aplicado, debido a que requiere de conocimientos y herramientas provenientes de áreas de conocimiento externos al manejo de cuencas. La propuesta fundamental es transitar de un sistema reduccionista, a un enfoque holístico en el manejo de cuencas, a través de la aplicación de los conceptos teóricos de los espacios de Hilbert. A diferencia de propuestas que han abordado el tema desde una perspectiva más conceptual que operacional, como la de Garcés (2011), la propuesta metodológica presentada considera su aplicación como herramienta de planeación y toma de decisiones.

\section{Marco teórico}

\section{Sistema reduccionista}

Hay una gran diversidad de enfoques para abordar la relación entre la realidad y las ciencias que la caracterizan, normalizan y explican. Cualquier abordaje a estas relaciones se basa en presupuestos filosóficos. La base filosófica de cualquier ciencia establece las características del campo de conocimiento, desarrollado a partir de un proceso de investigación definido como relaciones de primer orden. En cambio, la metafísica establece el análisis de las características más generales de la realidad como relaciones de segundo orden (Zela, 2013).

Se define a la ciencia como el estudio empírico del orden que regula las relaciones entre los subsistemas naturales; filosóficamente definido como materialismo científico. Se busca generar conocimiento a partir de bases comprobables en el espacio material-físico perfectamente limitado (Universo), definido como datos empíricos sensoriales (variables) que están contenidos en sistemas homogéneos (conjuntos), y relacionados a través de estructuras lógicoreduccionistas que explican los fenómenos de forma simplista (funciones). La Figura 1 muestra la estructura reduccionista de la realidad (Russell, Stoeger, \& Coyne, 2004; Luna, 2012). 


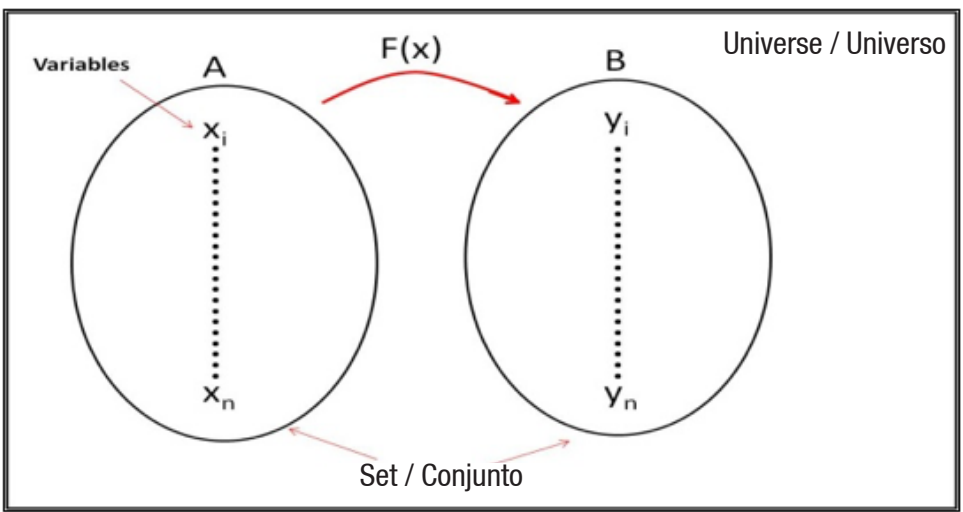

Figure 1. Definition of Universe

Figura 1. Definición de Universo

Source: Author-made / Fuente: Construcción propia

Another characteristic is that the relationship between set $A$ and $B$ is only from one element of $A$ to one element of set $B$, that is, univocal and directed. This analysis system has the limitation that only the controllable variables within a field of specialization are identified (Ackoff, 1997).

Scientific materialism is a reductionist process. Epistemological reductionism establishes that scientific laws and theories are totally reducible to simplified processes of the physical and chemical world (Calabrese, 1999). Thus, it is expected to explain reality through the relationships between its basic material components, defined as massto-energy transfer relationships, which would be the only verifiable causes in this world, known as variables (Uribarri, 2014; Luna, 2012). A limitation of the approach is that the explanations given of reality (cause-effect relationship) are not adapted to the totality of the universe, but to small spacetime elements, so that subspaces can be constructed where each established relationship is completely valid (Hilbert, 1904). Figure 2 shows this construction.

But this construction has a significant weakness: the cause-effect relationships of each subspace are not necessarily equal between them $(C(x) \neq G(x))$, but in the boundary between both subspaces it should be numerically equal ( $\operatorname{Bou}\left(C\left(x \Rightarrow v_{j}\right)=\operatorname{Bou}\left(G\left(x \Rightarrow k_{j}\right)\right.\right.$, which is not always true, presenting a paradox to the explanatory model. This paradox of scientific materialism is not enough to nullify it, because it has two assertions that give it solidity: a) the scientific
La condicionante de esta estructura que da base al planteamiento axiomático reduccionista es que el conjunto es continuo y, por lo tanto, la relación entre conjuntos, definida como relación causa-efecto, también es continua, y consecuentemente derivable. Otra característica es que la relación entre el conjunto $A$ y $B$ solo es desde un elemento de $A$ hasta un elemento del conjunto B, es decir, unívoca y direccionada. Este sistema de análisis presenta la limitante de que solo se identifican las variables controlables dentro de un campo de especialización (Ackoff, 1997).

El materialismo científico es un proceso reduccionista. El reduccionismo epistemológico establece que las leyes y las teorías científicas son totalmente reductibles a procesos simplificados del mundo físico y químico (Calabrese, 1999). Entonces, se espera explicar la realidad a través de las relaciones entre sus componentes materiales básicos, definidos como relaciones de transferencia entre masa $y$ energía, que serían las únicas causas verificables en este mundo, conocidas como variables (Uribarri, 2014; Luna, 2012). Una limitante del planteamiento es que las explicaciones dadas de la realidad (relación causaefecto) no se adaptan a la totalidad del universo, sino a pequeños elementos espacio-temporales, de tal forma que se pueden construir subespacios donde cada relación establecida es completamente válida (Hilbert, 1904). La Figura 2 muestra esta construcción.

Pero esta construcción presenta una debilidad importante: las relaciones causa-efecto de cada subespacio no necesariamente son iguales entre ellas $(C(x) \neq G(x))$, pero en el límite entre ambos subespacios 


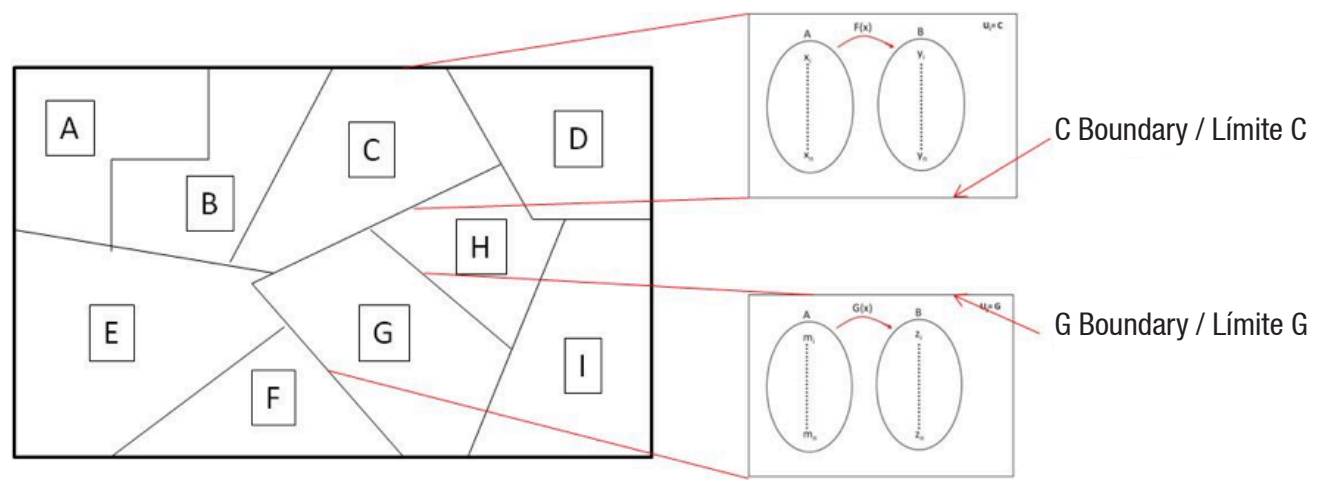

Figure 2. Cause-effect relationship

Figura 2. Relación causa-efecto

Source: Author-made / Fuente: Construcción propia

method, as the only reliable and verifiable path to knowledge and, b) the matter-energy binomial as the basis of the reality of the material universe. The first is an epistemological assertion about knowledge, based on a static reality (axiom); the second is a metaphysical assertion, which deals with the characteristics of higher realities with respect to the totality of the world, the world being the mesoscale sphere that encompasses the physical reality of the world and the relationships that regulate mass-to-energy transfers in an intangible way. These two elements are related under a very weak assumption from the philosophical point of view: only the entities and causes that are scientifically verifiable and that belong to the real world through measurable variables can be defined, studied and verified in nature, to establish their range of reality and their validity environment (Uribarri, 2014). Under this paradigm, historical, anthropological and psychological spaces and the whole range of knowledge associated with time are not considered as science, as they are not verifiable, analyzable, repeatable and susceptible to being synthesized through a function.

\section{Complex systems}

Separate analysis of the parts of a system is useful to characterize the static reality of the world, but it excludes the relationships between its components and the organizational structures of the higher levels of the system itself, as well as the relationships established between the complex system, with broader sets of the material world and the debiera ser numéricamente igual $(\operatorname{Lim}(C(x \Rightarrow v)=$ $\operatorname{Lim}\left(G\left(x \Rightarrow k_{j}\right)\right.$, lo que no siempre se cumple, presentando una paradoja al modelo explicativo. Esta paradoja del materialismo científico no es suficiente para anularlo, debido a que tiene dos asertos que le dan solidez: a) el método científico, como único camino confiable y verificable del conocimiento $y, b$ ) el binomio materiaenergía como base de la realidad del universo material. El primero es un aserto epistemológico sobre el conocimiento, asentado en una realidad estática (axioma); el segundo es un aserto metafísico, que trata sobre las características de las realidades superiores respecto a la totalidad del mundo, siendo el mundo la esfera a mesoescala que abarca la realidad física del mundo y las relaciones que norman las transferencias de masa-energía de forma intangible. Estos dos elementos se relacionan bajo un supuesto muy endeble desde el punto de vista filosófico: solo las entidades y causas que son científicamente verificables, y pertenecen al mundo real a través de variables mesurables, pueden ser definidas, estudiadas y verificadas en la naturaleza, para establecer su rango de realidad y su entorno de vigencia (Uribarri, 2014). Bajo este paradigma los espacios históricos, antropológicos, psicológicos y toda la gama de saberes asociados al tiempo no son considerados como ciencia, al ser no verificables, analizables, repetibles y susceptibles de ser sintetizados a través de una función.

\section{Sistemas complejos}

El análisis por separado de las partes de un sistema es útil para caracterizar la realidad estática del 
intangible world (Velásquez, 2007). Some currents of naturalism have attempted to address the next organizational level of reality. They postulate that the reductionist system is not applicable to higher levels of organization, because they do not necessarily replicate the base structure (verifiable system), and because there are also going to be relationships at the lower levels that do not exist at the higher ones. This concept is defined as an emergent property of reality and establishes that different characteristics will exist between the lower levels of aggregation and the higher levels of the same phenomenon. Under this paradigm the sociological spaces, with their range of changes associated with time, are integrable to the analysis, and even more, it establishes higher-order relationships with the basic levels (Coleman, 2001).

An epistemological basis is the significant language structure that underpins sciences and knowledge. Basically they are logical-abstract sentences that relate the elements of the base level with those of the higher levels through empirical assumptions verifiable through the senses. On the contrary, the statements derived from social phenomena are neither true nor false. In this sense, sociological assertions are statements lacking direction (positive-negative from a referential point); they are expressions of emotions, human preferences, individual perceptions, or sociopsychological interpretations lacking cognitive meaning, that is, they do not generate universal knowledge, known as positivism. The main criticism of positivism is based on the fact that empirical data presuppose an unquestionable (axiomatic) cause-effect relationship. Thus, the elements that constitute the system are conceptually organized and the organizational processes of the higher levels (metaphysics) are spurned. This means that the interactions between human interventions and their consequences in the material world are not measurable because they are subjective and directed by the surrounding temporal conditions, eliminating the immutable and repeatable nature of scientific concepts and questioning the application of the scientific method (Uribarri, 2014; Russell et al., 2004; Villalpando, 2008; Coleman, 2001).

The alternative to positivism is complex analysis. It recognizes that reality is made up of different mundo, pero excluye las relaciones entre sus componentes y las estructuras de organización de los niveles superiores del propio sistema, así como las relaciones que se establecen entre el sistema complejo, con conjuntos más amplios del mundo material y del mundo intangible (Velásquez, 2007). Algunas corrientes del naturalismo han intentado abordar el siguiente nivel organizativo de la realidad. Postulan que el sistema reduccionista no es aplicable a niveles superiores de organización, debido a que no necesariamente replican la estructura base (sistema verificable), y a que también se van a dar relaciones en los niveles inferiores que no existen en los niveles superiores. Este concepto es definido como una propiedad emergente de la realidad y establece que van a existir características diferentes entre los niveles de agregación inferiores y los niveles superiores de un mismo fenómeno. Bajo este paradigma los espacios sociológicos, con su gama de cambios asociados al tiempo, son integrables al análisis, y aún más, establece relaciones de orden superior con los niveles básicos (Coleman, 2001).

Una base epistemológica es la estructura de lenguaje significativo que fundamenta ciencias y saberes. Básicamente son sentencias lógico-abstractas que relacionan los elementos del nivel base, con los elementos de los niveles superiores, a través de presupuestos empíricos y verificables por los sentidos. De forma contraria, los enunciados derivados de los fenómenos sociales no son ni falsos ni verdaderos. En este sentido, las aseveraciones sociológicas son enunciados carentes de dirección (positiva-negativa a partir de un punto referencial), son expresiones de emociones, preferencias humanas, percepciones individuales, o interpretaciones sociopsicológicas carentes de significado cognitivo, es decir, que no generan conocimiento universal, conocido como positivismo. La crítica principal al positivismo se basa en que los datos empíricos presuponen una relación causa-efecto incuestionable (axiomática). Entonces, los elementos que constituyen al sistema están conceptualmente organizados y se desprecian los procesos organizativos de los niveles superiores (metafísica). Esto significa que las interacciones entre las intervenciones humanas y sus consecuencias en el mundo material no son mesurables por ser subjetivas y direccionadas por las condiciones temporales 
organizational levels, where reductionist and open aspects are combined, through metaphysical assumptions, to generate non-homogeneous spaces. Also, being systems where social aspects are not measurable, there will be subspaces that cannot be parameterized, but can be characterized, which guarantees a gradual change of the system, expressed by: $\frac{\partial C}{\partial F r} \cong \frac{\partial G}{\partial F r} \sim 0$, which in numerical terms is a forcing that guarantees the connection (continuity) between subspaces, with gradual changes (derivable) (Muñoz, 2014).

Likewise, García (2006) states that reductionism is not contrary to complex construction, by postulating that the response of a system is more than a causeeffect relationship (function), and neither is it the sum of the parts, but the combination of them. In other words, complex construction is based on a discretization of the universe into homogeneous subsystems that allows its management from the reductionist perspective, but establishes metaphysical relationships through numerical forcing that guarantees continuity among the subsystems, from $\frac{\partial C}{\partial F r}=\frac{\partial C}{\partial x}, \frac{\partial C}{\partial y}, \frac{\partial C}{\partial z} \neq 0 ;$ this construction is going to present a behavior and a trend that relates subspaces that are not neighbors (Muñoz, 2014). Figure 3 shows this construction.

The benefits of building a complex system are that only the relationships that are considered significant for the phenomenon to be analyzed are established. Only the required variables and sets are integrated, so circundantes, eliminando la naturaleza inmutable y repetible de los conceptos científicos, y cuestionando la aplicación del método científico (Uribarri, 2014; Russell et al., 2004; Villalpando, 2008; Coleman, 2001).

La alternativa al positivismo es el análisis complejo. Reconoce que la realidad se compone de diferentes niveles organizativos, donde se combinan los aspectos reduccionistas con los abiertos, a través de presupuestos metafísicos, para generar espacios no homogéneos. Asimismo, al ser sistemas donde se integran aspectos sociales no mesurables, existirán subespacios que no serán parametrizables, pero si caracterizables, lo que garantiza un cambio gradual del sistema, expresado por: $\frac{\partial C}{\partial F r} \cong \frac{\partial G}{\partial F r} \sim 0$, que en términos numéricos es un forzamiento que garantiza la conexión (continuidad) entre subespacios, con cambios graduales (derivable) (Muñoz, 2014).

Asimismo, García (2006) establece que el reduccionismo no es contrario a la construcción compleja, al postular que la respuesta de un sistema es más que una relación causa-efecto (función), y tampoco es la suma de las partes, sino la combinación de ellas. Dicho de otra forma, la construcción compleja, se fundamenta en una discretización del universo en subsistemas homogéneos que permite su manejo desde la perspectiva reduccionista, pero establece relaciones metafísicas a través del forzamiento numérico que garantiza la continuidad entre los subsistemas, a partir de $\frac{\partial C}{\partial F r}=\frac{\partial C}{\partial x}, \frac{\partial C}{\partial y}, \frac{\partial C}{\partial z} \neq 0$; esta construcción va

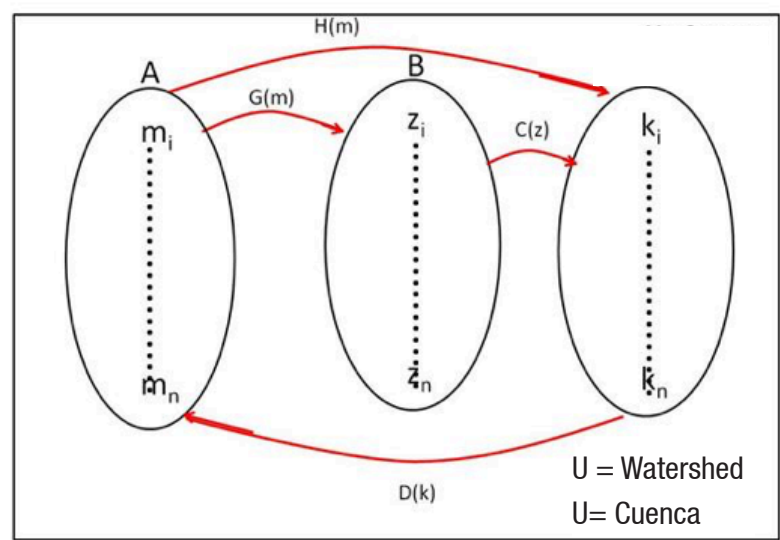

Figure 3. Discretization of the universe into homogeneous subsystems.

Figura 3. Discretización del universo en subsistemas homogéneos.

Source: Author-made / Fuente: Construcción propia 
the defined system determines the parameterization (intensity, density) of the chosen variables, which in conceptual terms is an indicator.

\section{Indicators}

Some indicators have been proposed based on the subjective identification of variables by expert panels, with a subsequent analysis justifying the selection. Consequently, there is a high possibility that the indicator will be biased and the final product will be an abstraction that is not understood outside the scope of its design. Experience has shown that an indicator should be developed from the analysis and compression of the system to be described, and where appropriate, monitored. They must be sensitive to changes, be demonstrable, and have easy to obtain base data.

Conceptually, an indicator is a reference point that gives qualitative or quantitative information, built from one or several specific data. The data can be perceptions, numbers, facts/opinions, measures, or anything that allows following the evolution of a phenomenon. They are a summary measure that allows through a single number to have an idea of what is happening; it is the combination of a set of variables, related through a second-order relationship of the form $l=f\left(v_{1}, v_{2} \ldots v_{n}\right)$ (Rojas, Pérez, Malheiros, Madera, Guimarães, Dos Santos, 2013).

There are other definitions of indicators, depending on the area of knowledge and needs. Compliance indicators are dichotomous (0.1), and reflect whether the objective was reached or not. Performance indicators are of the distributed type, and they evaluate the development, the phenomenon, through the monitoring of distributed variables (partial goals). Effect indicators measure whether specific objectives were met through a logical variable. Impact indicators, also called evaluation indicators, compare the initial stage with the final stage of the system or after an intervention; they have the form $I=F(t=$ final) $-F(t=$ initial), and are represented by the derivative of a function (Pacheco \& Contreras, 2008).

It is important to note that numerical variables, numerical function $(F(x))$, probabilistic function $(P(x))$, projection models $(F(x, t))$ and complex models (economic, production, marketing) are not indicators, but the combination of all of them can be an indicator, a presentar un comportamiento y una tendencia que relaciona subespacios que no son vecinos (Muñoz, 2014). La Figura 3 muestra esta construcción.

Las bondades de la construcción de un sistema complejo es que solo se establecen las relaciones que se consideran significativas para el fenómeno a analizar. Solo se integran las variables y los conjuntos requeridos, por lo que el sistema definido determina la parametrización (intensidad, densidad) de las variables elegidas, que en términos conceptuales es un indicador.

\section{Indicadores}

Algunos indicadores han sido propuestos a partir de la identificación subjetiva de variables por paneles de expertos, con un análisis posterior que justifica la selección. Consecuentemente, existe una alta posibilidad de que el indicador presente sesgos y el producto final sea una abstracción que no se entiende fuera del ámbito de su diseño. La experiencia ha mostrado que un indicador, debe desarrollarse a partir del análisis y compresión del sistema que va a describir, y en su caso, monitorear. Deben ser sensibles a los cambios, demostrables, y los datos base fáciles de obtener.

Conceptualmente, un indicador es un punto de referencia que da información cualitativa o cuantitativa, construido a partir de uno o varios datos puntuales. Los datos pueden ser percepciones, números, hechos/opiniones, medidas, o cualquier cosa que permita seguir la evolución de un fenómeno. Son una medida resumen que permite a través de un solo número tener una idea de qué está pasando; es la combinación de un conjunto de variables, relacionadas a través de una relación de segundo orden de la forma $l=f\left(v_{l}, v_{2} \ldots v_{n}\right)$ (Rojas, Pérez, Malheiros, Madera, Guimarães, Dos Santos, 2013).

Existen otras definiciones de indicadores, dependiendo del área de conocimiento y necesidades. Los indicadores de cumplimiento son de tipo dicotómico $(0,1)$, y reflejan si se alcanzó el objetivo o no. Los indicadores de desempeño son del tipo distribuido, y evalúan el desarrollo, el fenómeno a través del monitoreo de variables distribuidas (metas parciales). Los indicadores de efecto miden si se cumplieron los objetivos específicos a través de una variable lógica. Los indicadores de impacto, también 
if we return to the concept of a complex system that is constructed with reductionist spaces $\left(F(x), P(x), V_{i}\right)$. This conceptual basis allows mixing the responses of the subsystems through the construction of independent vectors of the form: $I=F(V i, P(x), F(x), \ldots)$. Another benefit of this construction is that the conceptual basis determines the set of variables to be used (orthogonal basis) and the degree of influence or significance on the process.

\section{Hilbert spaces}

The concept dates back to the philosophy of the 20th century, as a result of the works of David Hilbert, who in 1904 published a proposal for the consistency of mathematics to create axiomatic fields for almost any discipline. However, the success of his proposal was delimited by the works of Kurt Gödel (1986) who took this scheme and tested it in a series of axiomatic systems, finding that Hilbert's conclusions, although partial, could be extended to infinity to cover any space based on recursion. Regarding what Hilbert (1904) called inconsistency of theorems, Gödel (1986) called a partial formalized system (partial differential equation) and postulated his completeness theorem, which required the formalization of meta-varied and recursive systems. These concepts have been applied in the fields of astrophysics, physics, molecular chemistry, molecular biology, biotechnology and nanotechnology. This proposal develops their application in watershed management and natural resource assessment.

A logical system has the property of being consistent when it is not possible to deduce a contradiction within the system. That is, given a formal language and a deductive apparatus (axioms and rules of inference), it is not possible to deduce a formula and its negation. The existence of a model implies that a logical theory is consistent (Pacheco \& Contreras, 2008).

It is said that a logical system is decidable when, for any formula given in the language of a system with axioms and rules of inference, there is an effective method to determine whether or not that formula belongs or not to the set of system theorems. When a formula cannot be proved as a theorem, but neither can it be denied, it is said that the formula is independent and, therefore, the system llamados de evaluación, comparan el estadio inicial con el estadio final del sistema o después de una intervención; tienen la forma $l=F(t=$ final $)-F(t=$ inicial $)$, y se representan por la derivada de una función (Pacheco \& Contreras, 2008).

Es importante señalar que variables numéricas, función numérica $(F(x))$, función probabilística $(P(x))$, modelos de proyección $(F(x, t))$ y modelos complejos (económicos, producción, comercialización) no son indicadores, pero la combinación de todos ellos si puede ser un indicador, si retomamos el concepto de sistema complejo que se construye con espacios reduccionistas $\left(F(x), P(x), V_{i}\right)$. Esta base conceptual permite mezclar las respuestas de los subsistemas a través de la construcción de vectores independientes de la forma: $I=F(V i, P(x), F(x)$,...). Otra bondad de esta construcción es que la base conceptual determina el conjunto de variables a utilizar (base ortogonal) y el grado de influencia o significancia sobre el proceso.

\section{Espacios de Hilbert}

El concepto se remonta a la filosofía del siglo XX, como resultado de los trabajos de David Hilbert, quien publicó en 1904 una propuesta de la consistencia de las matemáticas para crear campos axiomáticos para casi cualquier disciplina. Sin embargo, el éxito de su propuesta fue acotado por los trabajos de Kurt Gödel (1986) quien tomó este esquema y lo probó en una serie de sistemas axiomáticos, encontrando que las conclusiones de Hilbert si bien eran parciales, podían extenderse al infinito para cubrir cualquier espacio con base en la recursividad. A lo que Hilbert (1904) llamó inconsistencia de los teoremas, Gödel (1986) lo llamó sistema formalizado parcial (ecuación diferencial parcial), y postuló su teorema de completes, que requería la formalización de sistemas metavariados y recursivos. Estos conceptos se han aplicado en los campos de la astrofísica, física, química molecular, biología molecular, biotecnología y nanotecnología. En esta propuesta se desarrolla su aplicación en el manejo de cuencas y en la evaluación de los recursos naturales.

Un sistema lógico tiene la propiedad de ser consistente cuando no es posible deducir una contradicción dentro del sistema. Es decir, dado un lenguaje formal y un aparato deductivo (axiomas y reglas de inferencia), no es posible deducir una fórmula y su negación. La existencia de un modelo 
is not decidable. The only way to incorporate an independent formula into the system's theorems is to postulate it as an axiom (Hilbert, 1904; Hilbert, 1927; Payá, 2008).

We talk about completeness in several senses, but perhaps the two most important are those of semantic completeness and syntactic completeness. A system $S$ in a language $L$ is semantically complete when all the logical truths of $L$ are $S$ theorems (Payá, 2008). On the other hand, a system $S$ is syntactically complete if, for every formula $A$ of the system language, $A$ is a theorem of $S$ or $A$ is a theorem of $S$. That is, there is a test for every formula or for its negation. Propositional logic and first-order logic are both semantically complete, but not syntactically complete. For example, note that, in propositional logic, the formula $p$ is not a theorem, and neither is its negation, so that it is enough to show that it is not syntactically complete. However, since neither of these formulas is a logical truth, they do not affect the semantic completeness of the system (Hilbert, 1904). Gödel's second incompleteness theorem shows that no system (recursively defined) with a certain expressive power can be both consistent and semantically complete.

Propositional logic as first-order logic satisfies the compactness theorem. That is, if from a set of propositions a consequence is followed, then there is a finite subset of propositions from which the same conclusion is followed. Similarly, if each finite set of propositions in a set admits a model, then the complete set admits to the model. Although firstorder logic has compactness in the sense previously explained, other more powerful logic forms such as second-order logic do not have the property of compactness (Payá, 2008).

\section{Application of Hilbert spaces to watershed management}

The need for human beings to control their environment is imperative. It gives them security to survive as individuals and as a society. In social and economic terms, at least three concepts of security are recognized: water, which refers to having volumes of available and safe water for their subsistence and community development; food, which refers to having food inventories that implica que una teoría lógica es consistente (Pacheco \& Contreras, 2008).

Se dice de un sistema lógico que es decidible cuando, para cualquier fórmula dada en el lenguaje de un sistema con axiomas y reglas de inferencia, existe un método efectivo para determinar si esa fórmula pertenece o no al conjunto de los teoremas del sistema. Cuando una fórmula no puede ser probada como teorema, pero tampoco se puede negar, se dice que la fórmula es independiente $y$, por lo tanto, el sistema es no decidible. La única manera de incorporar una fórmula independiente a los teoremas del sistema es postulándola como axioma (Hilbert, 1904; Hilbert, 1927; Payá, 2008).

Se habla de completes en varios sentidos, pero quizás los dos más importantes sean los de completitud semántica y completitud sintáctica. Un sistema $S$ en un lenguaje $L$ es semánticamente completo cuando todas las verdades lógicas de L son teoremas de $S$ (Payá, 2008). En cambio, un sistema $S$ es sintácticamente completo si, para toda fórmula $A$ del lenguaje del sistema, $A$ es un teorema de $S$ o $A$ es un teorema de $S$. Esto es, existe una prueba para cada fórmula o para su negación. La lógica proposicional y la lógica de primer orden son ambas semánticamente completas, pero no sintácticamente completas. Por ejemplo, nótese que, en la lógica proposicional, la fórmula $p$ no es un teorema, y tampoco lo es su negación, de modo que eso basta para mostrar que no es sintácticamente completa. No obstante, como ninguna de esas dos fórmulas es una verdad lógica, no afectan a la completitud semántica del sistema (Hilbert, 1904). El segundo teorema de incompletez de Gödel demuestra que ningún sistema (definido recursivamente) con cierto poder expresivo puede ser a la vez consistente y semánticamente completo.

La lógica proposicional como la lógica de primer orden satisface el teorema de compacidad. Es decir, si de un conjunto de proposiciones se sigue una consecuencia, entonces existe un subconjunto finito de proposiciones de las cuales se sigue la misma conclusión. Análogamente si cada conjunto finito de proposiciones de un conjunto admite un modelo, entonces el conjunto completo admite al modelo. Si bien la lógica de primer orden tiene compacidad en el sentido previamente explicado otras lógicas más 
guarantee food during the dry season or in times of poor agricultural production, and housing, which is the certainty that natural events do not threaten the physical integrity of individuals. At the next level is the generation of wealth: goods and services that make human existence comfortable. Watershed management is part of the strategies developed by man to manage and control his environment, in order to have security (ONU, 2014).

Resource management is the responsibility of government entities, who must plan, implement and evaluate the actions and strategies associated with resource exploitation. The whole of a strategy is framed in the public policies of governments, who establish evaluation protocols, such as indicators, to legitimize their actions. These indicators evaluate the progress, impact and fulfilment of strategies at each stage: program startup, program developmentprogress and program shutdown; this last stage is the one in which the greatest number of evaluations are implemented in order to identify the impact, progress and scope of the program.

The main problem with the evaluation schemes is that the indicators of each stage are absolute and are not related to the indicators of the preceding and subsequent stages, giving a fractured scheme that does not really reflect the impacts of the programs. In the case of watershed management, the disconnection between stages is more marked, given the complexity of the strategies. Therefore, it is a challenge to propose evaluation schemes that reflect the interventions in a watershed and maintain a connection between the phases (Galván, Bustamante, \& Ambriz, 2015).

The watershed is a physical, biological and human structure that meets all the conditions of a complex system. According to Figure 2, the watershed presents: a) a physical-conceptual border that limits the processes of mass-to-energy transfer to its interior (watershed); b) it is composed of subsystems (sub-basins) that maintain a certain degree of homogeneity that can be expressed by a causeeffect relationship (function), and c) the sub-basins maintain physical and functional continuity between their borders through second-order relationships. Figure 4 presents this structure. potentes como la lógica de segundo orden no tienen la propiedad de compacidad (Payá, 2008).

\section{Aplicación de los espacios de Hilbert al manejo de cuencas}

Para el ser humano es imperiosa la necesidad de controlar su entorno. Le da seguridad de sobrevivir como individuo y como sociedad. En términos sociales y económicos se reconocen al menos tres conceptos de seguridad: hídrica, que se refiere a contar con volúmenes de agua disponibles y seguros para su subsistencia y desarrollo de comunidades; alimentaria que se refiere a contar con inventarios de alimentos que garanticen la alimentación en época de estiaje o poca producción agrícola, y habitacional, que es la certeza de que los eventos naturales no amenazan la integridad física de los individuos. En el siguiente nivel está la generación de riqueza: bienes y servicios que hacen confortable su existencia. El manejo de cuenca es parte de las estrategias desarrolladas por el hombre para manejar y controlar su entorno, a fin de tener seguridad (ONU, 2014).

La gestión de los recursos recae en las entidades gubernamentales, quienes deben planificar, implementar y evaluar las acciones y estrategias asociadas a la explotación. La totalidad de una estrategia se enmarca en las políticas públicas de los gobiernos, quienes para legitimar sus acciones establecen protocolos de evaluación, como indicadores. Estos indicadores evalúan los avances, impactos, cumplimento de las estrategias, en cada etapa: arranque del programa, desarrollo-avance de este y cierre del programa; esta última fase es en la que se implementa el mayor número de evaluaciones, para identificar el impacto, el avance y los alcances del programa.

El principal problema que presentan los esquemas de evaluación es que los indicadores de cada etapa son absolutos y no están relacionados con los indicadores de las etapas antecedente y subsecuente, dando un esquema fracturado que no refleja realmente los impactos de los programas. En el caso del manejo de cuencas es más marcada la desconexión entre fases, dada la complejidad de las estrategias. Entonces, es un reto el proponer esquemas de evaluación que reflejen las intervenciones en una cuenca y mantengan 


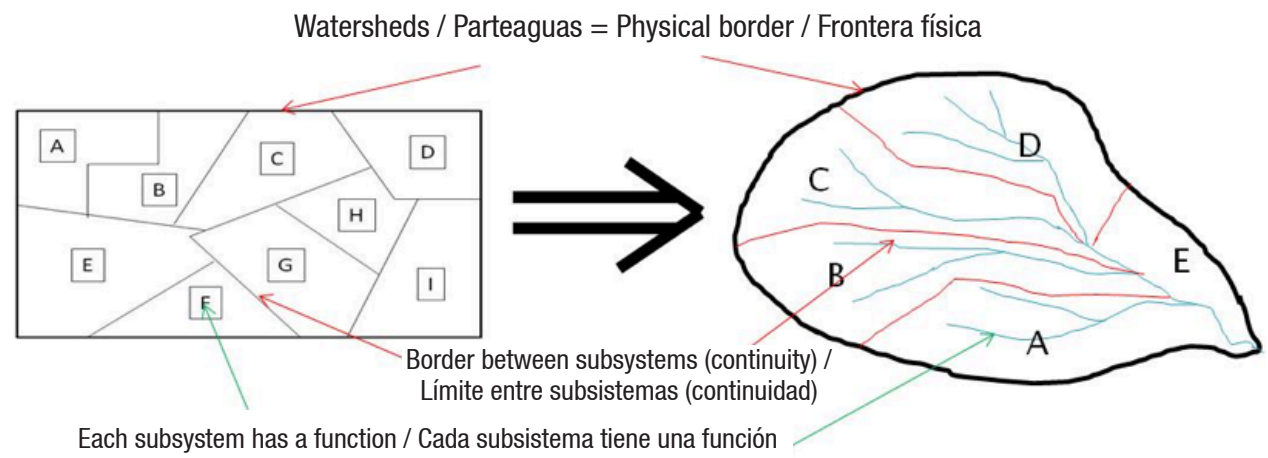

$(B(x)), A(z))$

Figure 4. Watershed structure associated with complex analysis.

Figura 4. Estructura de la cuenca asociada a análisis complejo.

Source: Author-made / Fuente: Construcción propia

The limits to which a productive system can be taken are marked by the physical and biological capacity of the watershed, combined with the technological and social capacity of the communities that inhabit it. The physical part is constituted by mass transfer processes such as runoff, sediment dragging, etc., defined by numerical functions; in the biological area there are transfer processes involving biological entities that depend on time and present some degree of randomness. Finally, human processes are not evaluable, there is no mass-energy transfer, and they have a strong dependence on time and social conditions, so they are multidimensional processes that cannot be represented by a function. The management of a watershed's potential refers to production capacity, expressed by: a) the proximity of the resources to be exploited (water and soil); b) the existence of roads, sources of electrical energy, topography and relief, and vegetation; and c) the technical-technological skills of individuals for the exploitation of resources (Corominas \& Franquesa, 2015).

The generation of indicators is the synthesis of all this information, through the application of numerical constructions that relate to the different subsets that make up the watershed. An implicit element of this whole concept is the temporality of the analyses and proposed solutions, which determines the validity and viability of said solutions, so that what is proposed for a certain space and time must be re-evaluated for each specific case (sub- conexión entre las fases (Galván, Bustamante, \& Ambriz, 2015).

La cuenca es una estructura física, biológica y humana que cumple con todas las condiciones de un sistema complejo. De acuerdo con la Figura 2, la cuenca presenta: a) una frontera físico-conceptual que limita los procesos de transferencia de masaenergía a su interior (parteaguas); b) está compuesta por subsistemas (subcuencas) que mantienen cierto grado de homogeneidad que puede ser expresada por una relación causa-efecto (función), y c) las subcuencas mantienen continuidad física y funcional entre sus fronteras a través de relaciones de segundo orden. La Figura 4 presenta esta estructura.

Los límites a los que se puede llevar un sistema productivo están marcados por la capacidad física y biológica de la cuenca, combinado con la capacidad tecnológica y social de las comunidades que la habitan. La parte física se constituye por los procesos de transferencia de masa como escurrimientos, arrastre de sedimentos, etc., definidos por funciones numéricas; en el ámbito biológico se encuentran los procesos de transferencia que involucran entes biológicos que dependen del tiempo y presentan algún grado de aleatoriedad. Por último, los procesos humanos no son evaluables, no hay transferencia de masa-energía, y tienen una fuerte dependencia del tiempo y las condiciones sociales, por lo que son procesos multidimensionales que no pueden ser representados por una función. El manejo 
basin) in which they are intended to be applied, through the similarity between the definition factors. It is an analysis system open in space and time.

The systems approach proposes that the relationships between the second-order components be of a large scale and with a random component, which are associable to biological processes, whereas for the internal relationships of the subsystem defined as first-order relationships (functions), it is required that the phenomena be well defined and unidirectional in space and time, which are associable to rain-runoff models, for example.

This structure is defined by $Z=H(g(s, q, r))$, where $Z$ is the second-order relationship, while $g$ is the first-order relationship, and $s, q$ and $r$ are measurable system variables. Regarding the conceptual structure, it is represented in Figure 5.

The indicator's construction is taken as a mathematical basis to generate a theoretical basis, associating it with Hilbert spaces. A Hilbert space is defined as an infinitely large vector space. The need to postulate an infinitely large vector space is to integrate a whole system of variables on a rigorously formal mathematical basis. It proposes that vector components not be limited to real numbers (it contemplates complex and imaginary ones), while redefining the concept of the internal product of two de la potencialidad de una cuenca se refiere a la capacidad de producción, expresada por: a) la proximidad de los recursos a explotar (agua y suelo); b) la existencia de caminos, fuentes de energía eléctrica, topografía y relieve, y vegetación, y c) las habilidades técnico-tecnológicas de los individuos para la explotación de los recursos (Corominas \& Franquesa, 2015).

La generación de indicadores es la síntesis de toda esta información, a través de la aplicación de construcciones numéricas que relacionan a los diferentes subconjuntos que componen la cuenca. Como un elemento implícito de todo este concepto está la temporalidad de los análisis y soluciones propuestas, lo que determina la validez y viabilidad de dichas soluciones, de tal forma que lo propuesto para determinado espacio y tiempo deberá ser reevaluado para cada caso específico (subcuenca) en que se pretendan aplicar, a través de la similitud entre los factores de definición. Es un sistema de análisis abierto en espacio y tiempo.

El enfoque de sistemas plantea que las relaciones entre los componentes de segundo orden sean de gran escala y con una componente aleatoria, que son asociables a los procesos biológicos; mientras que para las relaciones internas del subsistema definidas como relaciones de primer orden (funciones) se requiere que

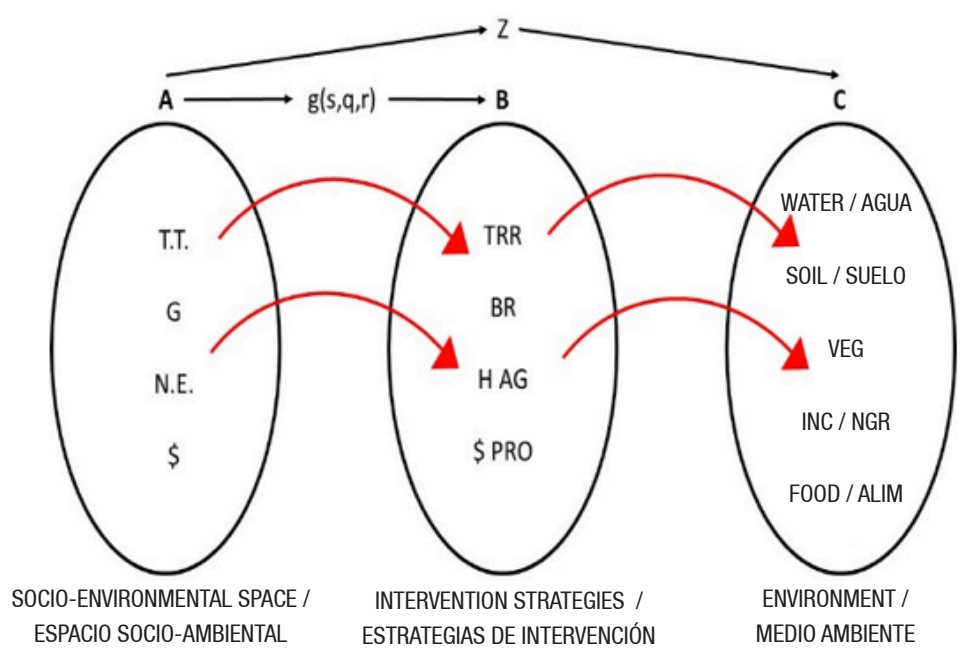

Figure 5. Conceptual structure

Figura 5. Estructura conceptual

Source: Author-made / Fuente: Construcción propia 
vectors $\left(\mathrm{V}_{1} \mathrm{x}_{2}\right)$ outside the world of the real ones, so that this product can have a physical meaning (Payá, 2008), Figure 6.

Subsequently, a Gram-Schmidt orthogonalization process is applied, which takes a set of base vectors (linearly independent, which implies that one of the vectors cannot be obtained through a linear combination of the others) to construct an orthonormal set of base vectors, which applied to the watershed results in (Figure 7):

This means, in the case of the watershed, that each (heterogeneous) system will have its own set of variables, defined in density and intensity, grouped into homogeneous sets, distributed spatially and temporally (vector), which generate heterogeneous responses. The strength of these postulates lies in the fact that vector space:

a) Can include diverse variables

b) Is infinitely large (A matrix of vectors)

c) Being a vector space defined in the domain los fenómenos sean bien definidos y unidireccionales en espacio y tiempo, que son asociables a modelos lluvia-escurrimiento, por ejemplo.

Se define a esta estructura por $Z=H(g(s, q, r))$, donde $Z$ es la relación de segundo orden, mientras $g$ es la relación de primer orden, y s, $q$ y $r$ son variables mesurables del sistema. Respecto a la estructura conceptual se representa en la Figura 5.

La construcción del indicador se toma como base matemática para generar una base teórica: asociarlo a los espacios de Hilbert. Un espacio de Hilbert es definido como un espacio vectorial infinitamente grande. La necesidad de postular un espacio vectorial infinitamente grande es para integrar todo un sistema de variables sobre una base matemática rigurosamente formal. Propone que los componentes vectoriales no se limiten a números reales (contempla complejos e imaginarios), redefiniendo a la vez el concepto del producto interno de dos vectores $\left(\mathrm{V}_{1} \mathrm{xV}_{2}\right)$ fuera del mundo de los reales,

$$
\left[\begin{array}{c}
\text { IF } \\
\text { Ibio } \\
\text { Ihum }
\end{array}\right]=\left[\begin{array}{c}
A_{21} X_{21}+A_{22} X_{2}+\ldots . A_{2 n} X_{2 n} \\
A_{31} X_{31}+A_{32} X_{32}+\ldots . A_{3 n} X_{3 n} \\
A_{41} X_{41}+A_{42} X_{42}+\ldots . A_{4 n} X_{4 n}
\end{array}\right] \begin{aligned}
& \text { Infinitely large vector space / } \\
& \text { Espacio vectorial infinitamente grande }
\end{aligned}
$$

Figure 6. Vector space

Figura 6. Espacio vectorial

Source: Author-made / Fuente: Construcción propia

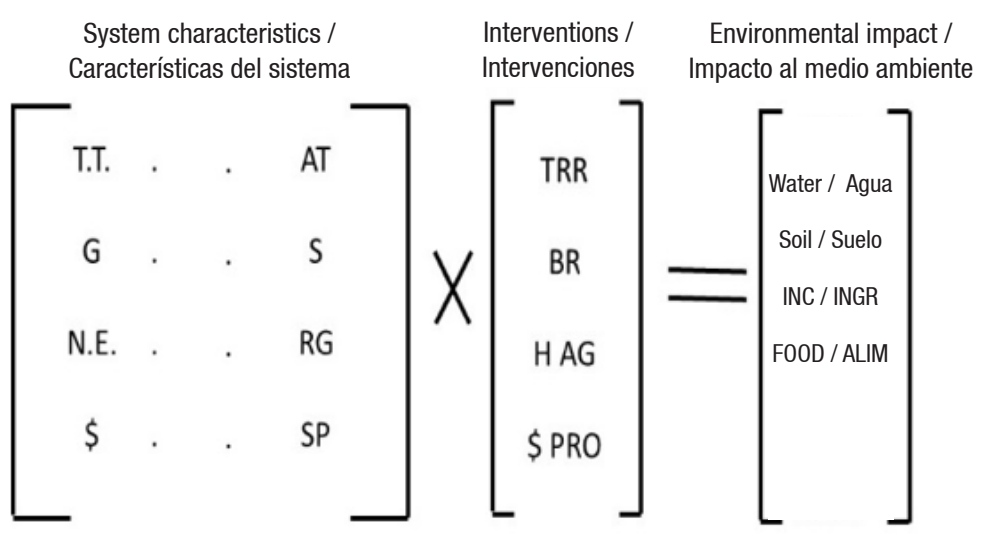

Figure 7. Orthonormal set of vectors

Figura 7. Conjunto ortonormal de vectores

Source: Author-made / Fuente: Construcción propia 
of real numbers, it is possible to apply the inverse problem

The postulates applicable to the problem of watersheds are the Complete ones, which says that every phenomenon (vector space) fits in the system, but if it does not meet any condition (axiom), a new subsystem (axiom) can be built that gives it a framework, making the initial system grow or complete; Continuity says that the passage between subsystems exists, has real value and is measurable, that is, there are no information gaps.

Based on these assertions, a system is defined as a collection of sets of diverse elements, which are interrelated and that fulfill the following properties:

1. The properties or behavior of each part of the set have an effect on the properties or behavior of the set as a whole.

2. The properties and behavior of each part, and how it affects the whole, depend on the properties and behavior of at least one other part of the set. Therefore, no part has an independent effect on the whole.

3. Every possible subgroup of elements in the set has the two previous properties.

Taking up the concept of the inverse problem, the output of the system that is required (forcing) can be considered, and having the characteristics of the system, the interventions that should be performed to achieve the proposed forcing are deduced numerically (Figure 8). para que dicho producto pueda tener un significado físico (Payá, 2008), Figura 6.

Posteriormente, se aplica un proceso de ortogonalización Gram-Schmidt, el cual toma un conjunto de vectores de base (linealmente independientes, lo cual implica que no se puede obtener uno de los vectores mediante una combinación lineal de los demás) para construir un conjunto ortonormal de vectores de base, que aplicado a la cuenca queda (Figura 7): esto significa, en el caso de la cuenca, que cada sistema (heterogéneo) tendrá su propio conjunto de

variables, definidas en densidad e intensidad, agrupadas en conjuntos homogéneos, distribuidas espacial y temporalmente (vector), que generan respuestas heterogéneas. La fortaleza de estos postulados radica en que el espacio vectorial:

a) Puede incluir variables diversas

b) Es infinitamente grande (Una matriz de vectores)

c) Por ser un espacio vectorial definido en el dominio de los números reales, es posible aplicar el problema inverso

Los postulados aplicables al problema de cuencas son la Completes, que dice que todo fenómeno (espacio vectorial) cabe en el sistema, pero si no cumple alguna condición (axioma), se puede construir un nuevo subsistema (axioma) que le dé marco, haciendo crecer o completando el sistema inicial; la Continuidad dice que el paso entre subsistemas existe, tiene un valor real y es mesurable, es decir no hay vacíos de información.

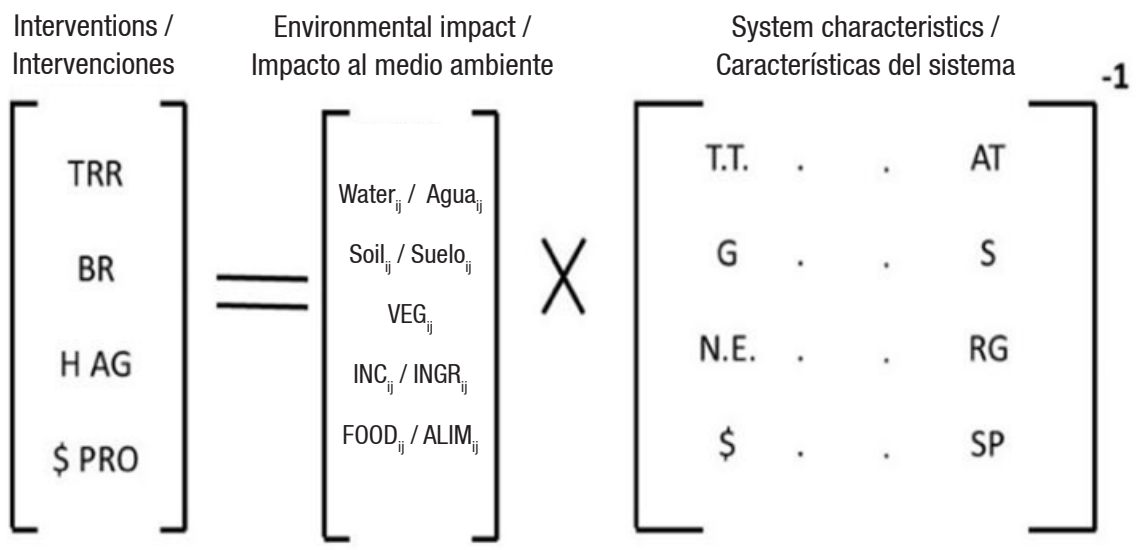

Figure 8. System output (orthonormal set of vectors)

Figura 8. Salida del sistema (conjunto ortonormal de vectores)

Source: Author-made / Fuente: Construcción propia 
The proposed system allows defining work scenarios, that is, a set of combinations of the interventions that are associated with the different impacts requested, but the most important thing is that the vector systems maintain their diversity, keep their physical meaning and, therefore, the base information system is recoverable.

\section{Application of the methodology}

A community intervention program in the rural area of Mexico City was evaluated to determine its efficiency and impact on the three areas involved with human welfare: the economic, environmental and social spheres (Galván et al., 2015). Of the programs operated in the 2013-2014 cycle, the Fund for the Support of Productive Projects (FAPPA) program was chosen because it was applied in Mexico City's seven rural boroughs: Tlalpan, Xochimilco, Milpa Alta, Tláhuac, Cuajimalpa, Álvaro Obregón and Magdalena Contreras, with the intention that it would be transversal on the three axes of sustainability. An indicator was constructed with socioeconomic and biophysical information with spatial scales at the local and regional level, based on data that can be easily fit to a numerical analysis. The information was obtained through a survey structured in 4 components, 13 sections and 280 variables. It was applied to 128 producers who received support from the aforementioned program, but, after reviewing the information, unanswered questions and inconsistencies were found in the partial and aggregated surface data and only the information from 63 producers was used. These producers have agricultural activity as a secondary activity and are distributed in 5 of the 7 rural boroughs: Cuajimalpa, Álvaro Obregón, Tláhuac, Tlalpan, and Milpa Alta. The variables were compared for the program's three execution times (startup, in its middle, shutdown), which is the derivative in time, to verify if there is continuity at each step.

The results show that there is discontinuity, as no program maintains the same variables in the three stages; $63 \%$ of the valuation variables are from the economic set, $32 \%$ from the social type, and the rest refer to very general data. The environmental space is totally absent. For the construction of the proposed indicator, the one for each variable was made to characterize them (type of variable), parameterize
A partir de estas aseveraciones se define a un sistema como la colección de conjuntos de elementos diversos, que están interrelacionados y que cumple con las siguientes propiedades:

1. Las propiedades o comportamiento de cada parte del conjunto tienen un efecto en las propiedades o comportamiento sobre el conjunto como un todo.

2. Las propiedades y el comportamiento de cada parte, y la forma en que este afecta el todo, dependen de las propiedades y comportamiento de al menos, otra parte del conjunto. Por lo tanto, ninguna parte tiene un efecto independiente sobre el todo.

3. Todo posible subgrupo de elementos en el conjunto presenta las dos propiedades anteriores.

Retomando el concepto del problema inverso, se pueden plantear la salida del sistema que se requiere (forzamiento), y teniendo las características del sistema, se deduce numéricamente las intervenciones que debieran realizarse para lograr el forzamiento planteado (Figura 8).

El sistema planteado permite definir escenarios de trabajo, es decir, un conjunto de combinaciones de las intervenciones que son asociadas a los diferentes impactos solicitados; pero lo más importante es que los sistemas vectoriales mantienen su diversidad, mantienen su significado físico $y$, por tanto, es recuperable el sistema de información base.

\section{Aplicación de la metodología}

Se evaluó un programa de intervención comunitaria en el área rural de la Ciudad de México para determinar su eficiencia e impacto en las tres áreas que interfieren con el bienestar humano: económica, ambiental y social (Galván et al., 2015). De los programas operados en el ciclo 2013-2014, se eligió el programa del Fondo para el Apoyo a Proyectos Productivos (FAPPA), debido a que fue aplicado en las siete delegaciones rurales de la Ciudad de México: Tlalpan, Xochimilco, Milpa Alta, Tláhuac, Cuajimalpa, Álvaro Obregón y Magdalena Contreras, con la intención de que fuera transversal sobre los tres ejes de la sustentabilidad. Se construyó un indicador con información socioeconómica y biofísica con escalas espaciales a nivel local y regional, basado en datos 
them (range of values that can be taken) and classify them within the value system (weight). With this, the base vector of each component was constructed, grouping the variables (data set) to generate the social, environmental and economic blocks, as a second matrix that is spatially organized (spatial neighbors). The information was grouped in blocks by component defined for each producer, where the location of the plot is the geographical base; due to the diversity of the variables, the data were normalized $(\chi, \sigma)$ to give homogeneity to the three axes.

The output of the calculations showed numerical instability. This is due to the low density of information, since the validation eliminated many producers, leaving many empty spaces. This resulted in a matrix with zero values, whose solution by definition is in the domain of the imaginary ones; on the other hand, significant variables are reflected with values in the domain of the real ones, while null variables are reflected as zero; with the estimated indicator, a distribution map was built at producer level; this information, being extensive, is not presented; Figure 9 shows this distribution. fácilmente ensamblables a un análisis numérico. La información se obtuvo a través de una encuesta estructurada en 4 componentes, 13 apartados y 280 variables. Se aplicó a 128 productores que recibieron apoyo del citado programa, pero, después de la revisión de la información, se encontraron preguntas sin contestar e inconsistencia en los datos parciales y agregados de superficie y solo se utilizó la información de 63 productores. Estos tienen actividad agrícola como secundaria y están distribuidos en 5 de las 7 delegaciones rurales: Cuajimalpa, Álvaro Obregón, Tláhuac, Tlalpan, y Milpa alta. Se compararon las variables para los tres tiempos de ejecución del programa (arranque, medio tiempo, cierre), que es la derivada en tiempo, para verificar si existe continuidad a cada paso.

Los resultados muestran que hay discontinuidad, ningún programa mantiene las mismas variables en las tres etapas, el $63 \%$ de las variables de valoración son del conjunto económico, $32 \%$ de tipo social, y el resto se refieren a datos muy generales. El espacio ambiental es totalmente ausente. Para la construcción del indicador propuesto se realizó el de

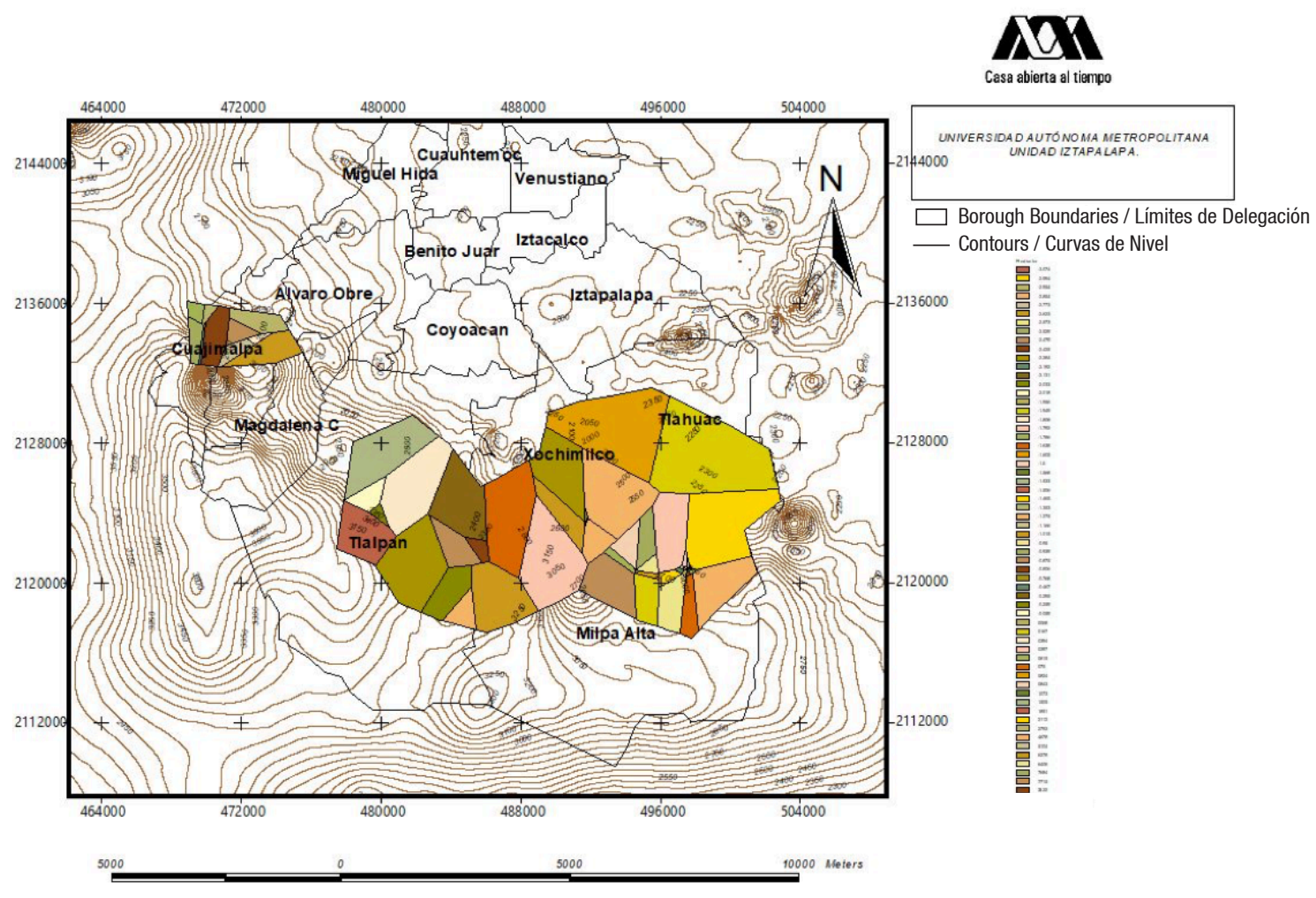

Figure 9. Indicator Distribution, Aggregation Level: Producer Figura 9. Distribución de Indicador, Nivel de agregación: Productor 
As can be seen, the location of the properties has a high spatial dispersion. In addition, there was individual variability and no correlation of information between neighboring producers.

In a second process, given that the work base is spatial, an aggregation of information was made, taking as a basis the location where the producer is located. It should be noted that some components are used in more than one system. Once grouped, the values were again normalized in order to have a homogeneous system. Table 1 shows this aggregation of information.

The result of this second approach is that the spatial gaps are increased; even one of the boroughs, Xochimilco, loses representation when the information from these producers is incorporated into Tláhuac, due to its geographical proximity. It can be seen that the greatest impact is on the economic component, which tangentially affects food and health and, therefore, the social component benefits. On the other hand, the impact on the cada variable para caracterizarlas (tipo de variable), parametrizarlas (rango de valores que puede tomar) y clasificarlas dentro del sistema de valores (peso). Con esto se construyó el vector base de cada componente, agrupando las variables (conjunto de datos) para generar los bloques social, ambiental y económico, como una segunda matriz que es organizada espacialmente (vecinos espaciales). La información se agrupó en bloques por componente definido para cada productor, donde la ubicación de la parcela es la base geográfica; debido a la diversidad de las variables, se normalizaron los datos $(\chi, \sigma)$ para dar homogeneidad a los tres ejes.

La salida de los cálculos presentó inestabilidad numérica. Esto es debido a la baja densidad de la información, dado que la validación eliminó a muchos productores, dejando muchos espacios vacíos. Esto resultó en una matriz con valores de cero, cuya solución por definición está en el dominio de los imaginarios; por otro lado, las variables significativas se reflejan con valores en el dominio de los reales,

Table 1. Survey data. Aggregated and normalized system

Cuadro 1. Datos de encuesta. Sistema agregado y normalizadost

\begin{tabular}{|c|c|c|c|c|c|c|c|c|c|c|}
\hline \multirow[b]{2}{*}{$\begin{array}{l}\text { Borough / } \\
\text { Delegación }\end{array}$} & \multicolumn{4}{|c|}{$\begin{array}{l}\text { ECONOMY (NORMALIZED) / } \\
\text { ECONOMÍA (NORMALIZADO) }\end{array}$} & \multicolumn{4}{|c|}{$\begin{array}{l}\text { ENVIRONMENT (NORMALIZED) / } \\
\text { AMBIENTE (NORMALIZADO) }\end{array}$} & \multicolumn{2}{|c|}{$\begin{array}{l}\text { SOCIAL (NORMALIZED) / } \\
\text { SOCIAL (NORMALIZADO) }\end{array}$} \\
\hline & $\begin{array}{c}\text { Property } \\
\text { characteristics / } \\
\text { Características } \\
\text { propiedad }\end{array}$ & $\begin{array}{c}\text { Productive } \\
\text { unit/ } \\
\text { Unidad } \\
\text { productiva }\end{array}$ & $\begin{array}{l}\text { Economy / } \\
\text { Economía }\end{array}$ & $\begin{array}{l}\text { Productivity / } \\
\text { Productividad }\end{array}$ & $\begin{array}{c}\text { Crop } \\
\text { management / } \\
\text { Manejo de } \\
\text { cultivos }\end{array}$ & $\begin{array}{l}\text { Livestock } \\
\text { farming / } \\
\text { Ganadería }\end{array}$ & $\begin{array}{l}\text { Sustainability / } \\
\text { Sustentabilidad }\end{array}$ & $\begin{array}{c}\text { Fuels / } \\
\text { Combustibles }\end{array}$ & $\begin{array}{l}\text { Health / } \\
\text { Salud }\end{array}$ & $\begin{array}{c}\text { Food/ } \\
\text { Alimentación }\end{array}$ \\
\hline Cuajimalpa & 4.50 & 6.02 & 4.98 & -1.91 & -1.86 & 2.25 & -1.79 & -1.19 & 2.43 & 19.24 \\
\hline $\begin{array}{l}\text { Álvaro } \\
\text { Obregón }\end{array}$ & 2.50 & 6.02 & 2.88 & -1.91 & -1.86 & -0.27 & -2.99 & -0.19 & 2.30 & 16.12 \\
\hline Tlalpan & 0.98 & 5.04 & 1.00 & -1.91 & -1.86 & -0.02 & -3.07 & -2.19 & 3.41 & 17.97 \\
\hline Milpa Alta & 1.98 & 4.01 & 2.07 & -1.91 & -1.86 & -0.27 & -2.99 & -0.19 & 2.30 & 16.12 \\
\hline Tláhuac & 3.98 & 5.00 & 5.32 & -1.91 & -1.86 & 2.08 & -2.48 & -1.69 & 5.38 & 20.76 \\
\hline Cuajimalpa & 4.77 & 6.03 & 6.50 & -1.91 & -1.86 & 3.00 & 0.26 & 2.31 & 4.40 & 20.00 \\
\hline $\begin{array}{l}\text { Álvaro } \\
\text { Obregón }\end{array}$ & 3.81 & 8.03 & 6.25 & 1.04 & 5.71 & 3.06 & 0.52 & 2.03 & 5.87 & 19.91 \\
\hline Tlalpan & 4.95 & 7.81 & 5.77 & 1.86 & 2.56 & 2.51 & 0.16 & 1.90 & 6.15 & 21.61 \\
\hline Milpa Alta & 3.71 & 7.43 & 4.13 & 1.67 & 2.62 & 2.37 & -0.25 & 4.68 & 4.91 & 19.44 \\
\hline Tláhuac & 4.00 & 5.04 & 5.49 & -1.91 & -1.86 & 3.61 & -1.78 & 0.76 & 5.71 & 20.94 \\
\hline Cuajimalpa & 5.03 & 6.04 & 7.46 & -1.91 & -1.86 & 4.81 & 7.68 & 3.70 & 6.40 & 21.20 \\
\hline $\begin{array}{l}\text { Álvaro } \\
\text { Obregón }\end{array}$ & 4.50 & 13.00 & 14.70 & 4.76 & 22.56 & 5.00 & 5.10 & 10.76 & 8.22 & 23.40 \\
\hline Tlalpan & 9.26 & 16.03 & 9.65 & 8.81 & 12.78 & 3.08 & 7.71 & 5.09 & 10.30 & 24.17 \\
\hline Milpa Alta & 5.09 & 13.04 & 7.91 & 14.78 & 2.62 & 2.37 & -0.25 & 4.68 & 13.11 & 23.64 \\
\hline Tláhuac & 4.03 & 5.08 & 5.66 & -1.91 & -1.86 & 5.13 & -1.60 & 2.70 & 6.03 & 21.12 \\
\hline
\end{tabular}


environmental component is very low, where most of the values are negative. This can be interpreted as a loss of environmental capital. A high dispersion of information is also maintained: the standard deviation becomes three times greater than the average for the intensity variables (yields, income, agrochemical application rates), but numerical instability is completely eliminated. Figure 10 shows the spatial distribution of this indicator.

This means that the producer profile is highly differentiated, so it was resolved with the definition of three typifications:

I. Minimum: subsistence producers.

II. Medium: producers with some elements with improvements, and other elements with losses.

III. Maximum: producers that in all the elements show improvements.

The methodology is again applied to the three differentiated blocks, the spatial basis being the borough distribution, and finally a value system is obtained where all are in the world of the real ones.

On the set of values obtained for each development axis, the hierarchy was made in five mientras que las variables nulas se reflejan como cero; con el indicador estimado se construyó un mapa de distribución a nivel productor; esta información, por ser extensa, no se presenta; la Figura 9 muestra esta distribución.

Como se aprecia, la ubicación de los predios tiene una alta dispersión espacial. Además, se tuvo variabilidad individual y no correlación de la información entre productores vecinos.

En un segundo proceso, dado que la base de trabajo es espacial, se hizo una agregación de información, tomando como base la localidad donde se asienta el productor. Cabe señalar, que algunos componentes se utilizan en más de un sistema. Una vez agrupados, se normalizaron nuevamente los valores, para tener un sistema homogéneo. El Cuadro 1 muestra esta agregación de información.

El resultado de este segundo acercamiento es que los vacíos espaciales se incrementan; incluso una de las alcaldías, Xochimilco, pierde representatividad al incorporase la información de estos productores a Tláhuac, debido a su cercanía geográfica. Se observa que el mayor impacto es sobre componente

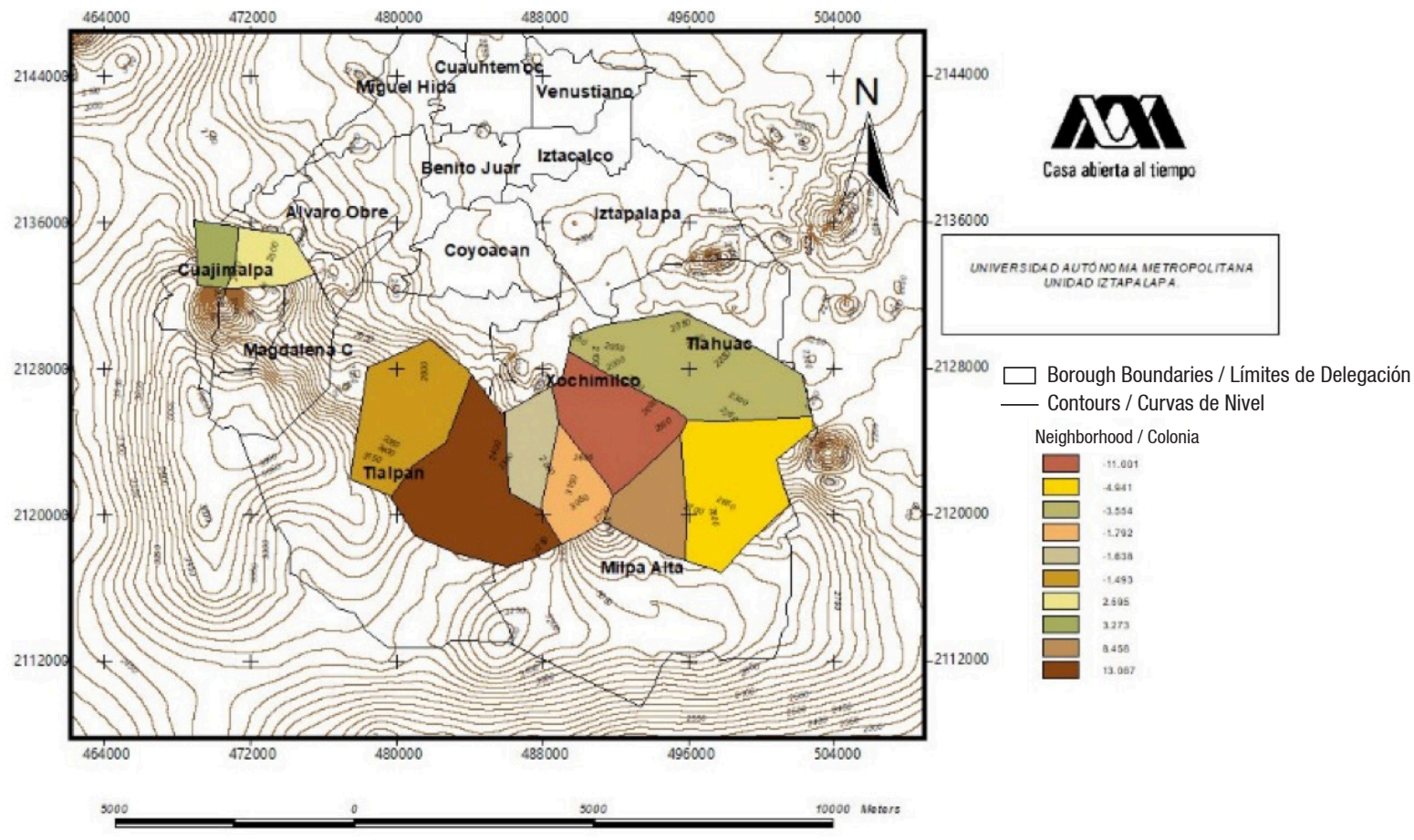

Figure 10. Indicator Distribution, Aggregation Level: Neighborhood

Figura 10. Distribución de Indicador, Nivel de agregación: Colonia 
equidistant ranges for each accumulation block (Table 2).

With the hierarchical indicators, Table 3 is obtained.

Differentiation into three spaces generates a numerically homogeneous system, but the comparison between spaces does reflect important económico, lo que incide tangencialmente en la alimentación y salud y por tanto el componente social se ve beneficiado. En contra parte, es muy bajo el impacto en el componente ambiental, donde mayoritariamente los valores son negativos. Esto se puede interpretar como una pérdida del capital ambiental. También se mantiene una alta dispersión

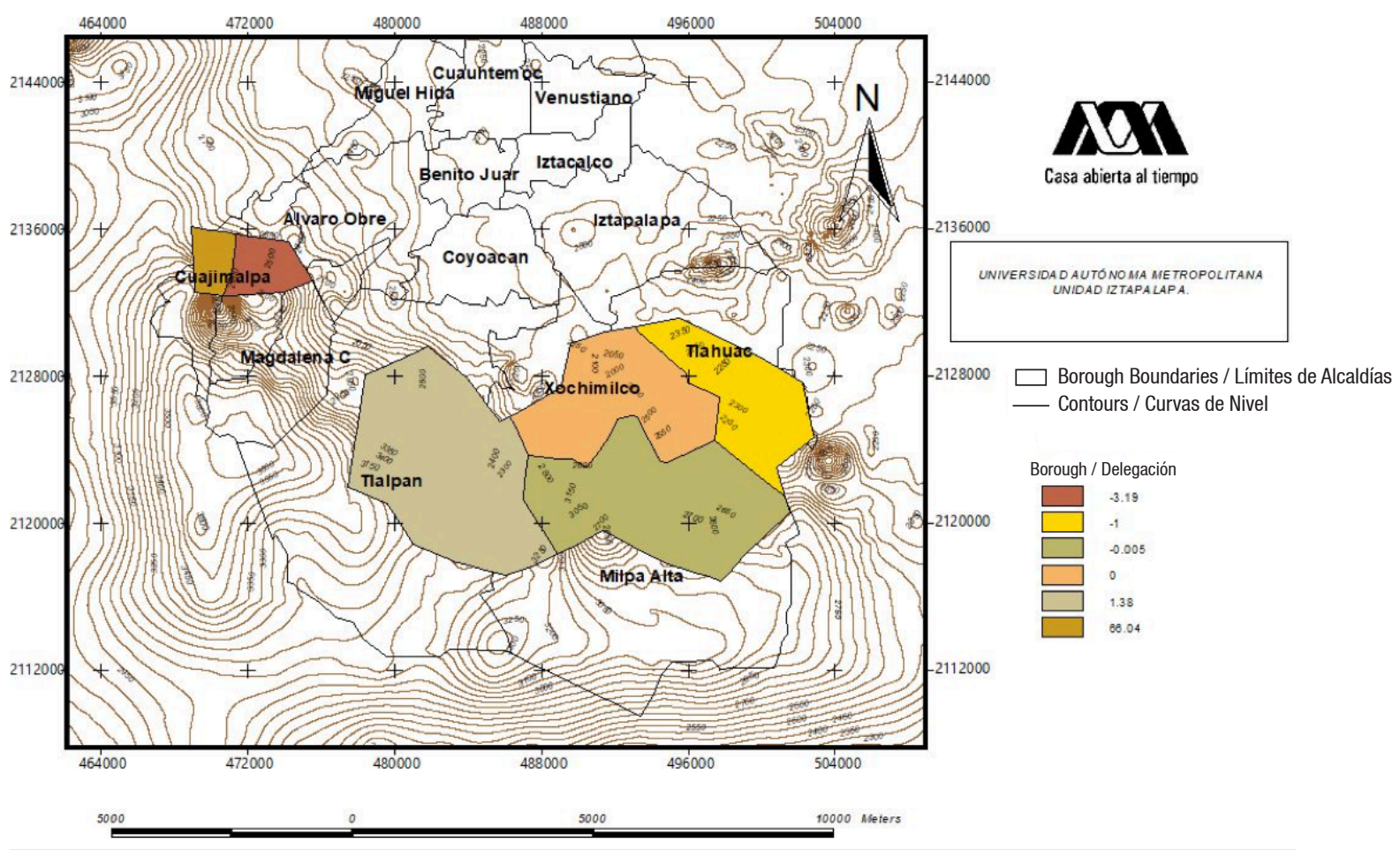

Figure 11. Indicator Distribution, Aggregation level: Borough

Figura 11. Distribución de Indicador, Nivel de agregación: Delegación

Table 2. Survey data. Aggregated and normalized system

Cuadro 2. Datos de encuesta. Sistema agregado y normalizado

\begin{tabular}{|c|c|c|}
\hline Performance / Desempeño & Attribute / Atributo & Banner / Bandera \\
\hline Very good / Muy bueno & $\begin{array}{l}\text { Value close to the maximum / } \\
\text { Valor cercano al máximo }\end{array}$ & \\
\hline Good/Bueno & $\begin{array}{l}\text { plus } 1 \text { standard deviation / } \\
\text { más } 1 \text { desviación estándar }\end{array}$ & \\
\hline Moderate / Moderado & $\begin{array}{c}\text { Around average / } \\
\text { Vecindad de la media }\end{array}$ & \\
\hline Poor / Pobre & $\begin{array}{l}\text { minus } 1 \text { standard deviation / } \\
\text { menos } 1 \text { desviación estándar }\end{array}$ & \\
\hline Very poor / Malo & $\begin{array}{l}\text { Value close to the minimum / } \\
\text { Valor cercano al mínimo }\end{array}$ & \\
\hline
\end{tabular}


Table 3. Resulting indicators, by component and geographical area

Cuadro 3. Indicadores resultantes, por componente y espacio geográfico

\begin{tabular}{lccccccccc}
\hline \multirow{2}{*}{ Borough } & \multicolumn{3}{c}{ ECONOMY VECTOR } & \multicolumn{2}{c}{ ENVIRONMENTAL VECTOR } & \multicolumn{3}{c}{ SOCIALVECTOR } \\
\cline { 2 - 11 } & Minimum & Medium & Maximum & Minimum & Medium & Maximum & Minimum & Medium & Maximum \\
\hline Cuajimalpa & 22.04 & 31.30 & 48.08 & -9.15 & 10.64 & 27.88 & 50.13 & 66.04 & 88.54 \\
Álvaro & 0.71 & 2.17 & 9.92 & -0.99 & -5.73 & -13.41 & -2.67 & -3.19 & -6.96 \\
Obregón & & & & & & & & & \\
Tlalpan & -0.38 & 0.00 & -4.06 & 0.81 & 2.24 & -0.54 & -0.07 & 1.38 & -6.96 \\
Milpa Alta & -0.38 & -0.31 & 1.39 & 0.00 & -0.38 & 0.01 & -0.07 & -0.01 & 0.01 \\
Tláhuac & 0.01 & -0.31 & 0.00 & 0.00 & 0.00 & 5.95 & -0.01 & -1.25 & -1.60 \\
\hline
\end{tabular}

changes. The borough with the least impact in the minimum space is Tlalpan, which has 7 out of 10 elements that are rated poor or very poor, and which also reports the highest expenditures on the subject; the second is Milpa Alta, which reports expenditures similar to Tlalpan. But in contrast, in the maximum space, the one with the greatest impact is Álvaro Obregón, followed by Tlalpan and Milpa Alta, which would justify the expenditures mentioned.

Finally, being dimensionless elements derived from a homogeneous numerical space, it is possible to add them up in order to have a comparison between boroughs, level and component; the indicators are ranked under the same classification of 5 ranges. Regarding the startup-operation and shutdown times (1, 2 and 3$)$, it is not possible to compare them since there is no comparable information for the 3 times.

We found a better defined pattern: only the Cuajimalpa borough has some degree of development in the three components, with stability between the minimum, medium and maximum levels; the rest of the boroughs show a uniform pattern of negative evaluation, in the three components and the three levels. We have a numerically stable and homogeneous system, and it is very important to note that the environmental vector again reflects the greatest losses.

The difference in indicators $I=F(t=$ final $)-F(t=$ initial $)$ can be applied between two contiguous spaces, or in the same space, for two different conditions. For example, in the Cuajimalpa borough the objective is to take a producer who is in the minimum range to the maximum range; in the economic vector, an increase of 26.04 indicator units is required, in the environmental vector 37.03 and in the social de la información: la desviación estándar llega a ser tres veces mayor que la media en el caso de las variables de intensidad (rendimientos, ingresos, tasas de aplicación de agroquímicos), pero se logra que la inestabilidad numérica desaparezca por completo. La Figura 10 presenta la distribución espacial de este indicador.

Esto significa que el perfil de productor es altamente diferenciado, por lo que se resolvió con la definición de tres tipificaciones:

I. Mínimos: productores de subsistencia.

II. Medios: productores con algunos elementos con mejoras, y otros elementos con pérdidas.

III. Máximos: productores que en todos los elementos presentan mejoras.

Sobre los tres bloques diferenciados se aplica nuevamente la metodología, siendo la base espacial la distribución delegacional, y se obtiene finalmente un sistema de valores donde todos están en el mundo de los reales. La Figura 11 presenta esta distribución espacial.

Sobre el conjunto de valores obtenidos por cada eje de desarrollo, se realizó la jerarquización en cinco rangos equidistantes por cada bloque de acumulación (Cuadro 2).

Con los indicadores jerarquizados se obtiene el Cuadro 3.

La diferenciación en tres espacios genera un sistema homogéneo numéricamente hablando, pero la comparación entre espacios si refleja cambios importantes. En el espacio de mínimos la delegación con menos impacto es Tlalpan al tener 7 de 10 elementos de mal a muy mal calificados, y que además reporta las mayores erogaciones en el tema; la segunda es Milpa Alta que reporta erogaciones similares a Tlalpan. Pero en contraste, en el espacio 
one 38.41; this means that by taking a variable from the environmental vector, for example, waste disposal that is part of the sustainability vector, its management must be improved by $7.35 \%$ to reach the medium level and by $6.39 \%$ more to reach the maximum level (self-contained system). However, if we compare two spaces, Cuajimalpa, which is the best rated with a value of 27.88 , and Tláhuac, which has a value of 5.95 , the required improvement is $78.15 \%$ for the same variable.

\section{Discussion}

Regarding the system of indicators proposed for the assessment of the FAPPA program, in a disaggregated format the numerical system is unstable and therefore not applicable. In medium level aggregation (neighborhood) the system goes out of the space of imaginary numbers, but the values are mostly negative, meaning that the program did not produce improvement in any of the development axes. The space can be classified as "poor" in all three systems, where the lowest level and in all boroughs is held by the environmental system, while the best rated is the social system. In the two approaches there is no geographical pattern (distribution by boroughs) or by levels of continuity (minimum-medium-maximum condition).

At the level of aggregation by borough, we find a better defined pattern: first, only the Cuajimalpa borough shows some degree of development in all three systems; the rest of the boroughs show a uniform and negative pattern in all three systems and for the components. According to the data, overall the economic vector in the program accounts for $56.39 \%$ of the budget allocation, the social vector represents $39.84 \%$ and the environmental vector only $3.75 \%$.

The proposed evaluation system allows defining a set of combinations of the variables that generate different vectors, provided that a fixed base is maintained that gives continuity between the scenarios. This construction allows the generation of different numerical outputs, which are associated with the different a) conditions, b) aggregations, and c) execution times (GramSchmidt orthogonalization process). de máximos, la de mayor impacto es Álvaro Obregón, seguida de Tlalpan y Milpa Alta, lo que justificaría las erogaciones mencionadas.

Finalmente, al ser elementos adimensionales derivados de un espacio numérico homogéneo, es posible realizar la suma de estos, a fin de tener una comparación entre delegaciones, nivel y componente, se jerarquizan los indicadores bajo la misma clasificación de 5 rangos. Respecto a los tiempos de arranque-operación y cierre $(1,2$ y 3$)$ no es posible realizar la comparación, dado que no existe información de los 3 tiempos que sea equiparable.

Encontramos un patrón mejor definido: solo la delegación Cuajimalpa presenta algún grado de desarrollo en los tres componentes, hay estabilidad entre los niveles mínimo, medio y máximo; el resto de las delegaciones muestran un patrón uniforme de evaluación negativa, en los tres componentes y los tres niveles. Tenemos un sistema estable numéricamente y homogéneo, y es muy importante notar que el vector ambiental nuevamente es el que refleja las mayores pérdidas.

Se puede aplicar la diferencia de indicadores $I=F(t=$ final) $-F(t=$ inicial) entre dos espacios contiguos, 0 en un mismo espacio, para dos condiciones diferentes. Por ejemplo, en la delegación Cuajimalpa se desea llevar a un productor que está en el rango mínimo, al rango máximo; en el vector económico se requiere un incremento de 26.04 unidades de indicador, en lo ambiental de 37.03 unidades de indicador y en lo social es de 38.41 unidades de indicador; significa que tomando una variable del vector ambiental, por ejemplo, disposición de residuales que es parte del vector de sustentabilidad, se debe mejorar en un $7.35 \%$ su manejo, para llegar al nivel medio, y en un $6.39 \%$ más, para llegar al nivel máximo (sistema auto contenido). Pero si se comparan dos espacios, Cuajimalpa que es el mejor calificado con valor de 27.88, respecto a Tláhuac con valor de 5.95, la mejora requerida es de $78.15 \%$ para la misma variable.

\section{Discusión}

Respecto al sistema de indicadores propuesto para la valoración del programa FAPPA, en formato desagregado el sistema numérico es inestable, por lo que no es aplicable. En agregación de nivel medio 
The methodology maintains the base information (fixed-continuous base), so that, when comparing vector spaces, it is possible to identify the improvement required in the variables that make up a vector; this is the axiomatic base proposed by John Von Neumann for Hilbert spaces. This base information is complemented with other variables that are specific to the scenario to be evaluated defined as a volatile base, that is, the variables and numerical ranges in which it is found are defined by the system itself (self-contained system).

In this case the heterogeneity of the information comes from the density, and it is improved with spatial discretization; a numerical discretization (derivative) is also applied with the division into three efficiency ranges. This management represents the forcing of the function to be able to reduce the deviation: it is the management of the discontinuities, so that the spaces with a single point (Xochimilco) are added to the border of the contiguous space, which represents a differential increase of the matrix to an infinite matrix.

In reference to quantum leaps, in this case they are presented spatially, with information gaps and performance differences between boroughs; however, the numerical construction allows distinguishing these differences of the system without falling into instabilities (domain of the imaginary ones), and giving physical meaning to the result.

\section{Conclusions}

Applying the indicators to the data obtained in the survey allows us to conclude that the programs applied in the rural areas of Mexico City's boroughs did not have a section for the assessment of environmental conditions, so, from their definition, they lack a sustainable development perspective for communities.

To effectively assess the success of a watershed project, indicators must be generated in the three axes defined in the concept of sustainable development: economic, social and environmental. There is no consensus on this, except that the watershed is the unit of analysis, management and intervention for different purposes, mainly for water. This determines the formulation, execution, monitoring and evaluation of the interventions. (colonia) el sistema sale del espacio de los números imaginarios, pero los valores son negativos en su mayoría, esto significa que el programa no produjo mejora en ninguno de los ejes de desarrollo. El espacio puede ser catalogado como "pobre" en los tres sistemas, donde el nivel más bajo y en todas las delegaciones lo tiene el sistema ambiental, mientras que el mejor calificado es el sistema social. En los dos acercamientos no hay un patrón geográfico (distribución por delegaciones) ni por niveles de continuidad (condición de mínima-media-máxima).

En el nivel de agregación por delegación, encontramos un patrón mejor definido: en primer lugar, solo la delegación Cuajimalpa presenta algún grado de desarrollo en los tres sistemas; el resto de las delegaciones muestran un patrón uniforme y negativo en los tres sistemas y para los componentes. De acuerdo con los datos, de forma global el vector económico en el programa representa el $56.39 \%$ de la asignación presupuestal, el vector social representa el $39.84 \%$ y el ambiental solo el $3.75 \%$.

El sistema de evaluación planteado permite definir un conjunto de combinaciones de las variables que genera distintos vectores, siempre que se mantenga una base fija que dé continuidad entre los escenarios. Esta construcción permite generar diferentes salidas numéricas, que son asociadas a las diferentes a) condiciones, b) agregaciones, y c) tiempos de ejecución (Proceso de ortogonalización Gram-Schmidt).

La metodología mantiene la información base (base fija-continua), de tal forma que, al hacer comparativos entre los espacios vectoriales, es posible identificar la mejora requerida en las variables que componen a un vector; esta es la base axiomática planteada por John Von Neumann para los espacios de Hilbert. Esta información base es complementada con otras variables que son específicas del escenario a evaluar definida como base volátil, es decir, las variables y rangos numéricos en los que se encuentra se definen por el propio sistema (sistema autocontenido).

En este caso la heterogeneidad de la información proviene de la densidad, y se mejora con la discretización espacial; se aplica también una discretización numérica (derivada) con la división en tres rangos de eficiencia. Este manejo representa el 
The case study shows that the indicators generated from a perspective of the state of the system (characteristics of the biophysical space), as well as of the demand for the production of goods, allow the systematic evaluation of parameters through direct variables and the perceptions of the population.

The set of scenarios being hierarchized -in this case under a discrete system- allows visualizing the integral behavior of the system: evaluation from the perspective of the program's issuing entity.

The tool presented here allows carrying out an axis of evaluation of the program, from the planning, implementation, assessment and continuityshutdown, through multidimensional indicators, so that the personnel in charge of its execution have a monitoring and evaluation tool, and the receiving community has a way of rating the efficiency and impact of the program.

The conceptual tool to achieve this is the Hilbert spaces, which in turn have been operationalized by John Von Neumann and Gram-Schmidt. The numerical construction developed by these authors is applicable to the evaluation of watershed management in an integrated way: in the three development axes.

End of English version

\section{References}

Ackoff, R. L. (1997). El arte de resolver problemas. XII reimpresión. Ed. LIMUSA, Noriega Editores, México, D. F.

Calabrese, J. L. (1999). Ampliación de las fronteras del reduccionismo. Deducción y sistemas no lineales. Psicoanálisis APdeBA 21(3):431-453.

Coleman, J. S. (2001). Metateoría: La explicación en la Ciencia Social. Revista Colombiana de Sociología 6(2):193-218.

Corominas, M., \& Franquesa, J. (2015). Tennessee Valley Authority: una experiencia de planificación territorial modélica. Ciudad y Entorno 10(28):11-32.

Galván, F. A., Bustamante, A., \& Ambriz, J. J. (2015). Construcción de un indicador para la valoración de programas ambientales en la cuenca del valle de México: Aplicación de metodología. Revue Recherches en Sciences de Gestion-Management Sciences-Ciencias de Gestión 111:161-188. forzamiento de la función para lograr que la desviación se reduzca: es el manejo de las discontinuidades, de tal forma que los espacios con un solo punto (Xochimilco) son agregados a la frontera del espacio contiguo, lo que representa un incremento diferencial de la matriz a una matriz infinita.

En referencia a los saltos cuánticos, en este caso se presentan de forma espacial, con los vacíos de información y en las diferencias de desempeño entre las delegaciones, sin embargo, la construcción numérica permite distinguir estas diferencias del sistema sin caer en inestabilidades (dominio de los imaginarios), y dando sentido físico al resultado.

\section{Conclusiones}

La aplicación de los indicadores a los datos obtenidos en la encuesta permite concluir que los programas aplicados en las áreas rurales de las delegaciones del antiguo Distrito Federal no tuvieron un apartado de evaluación de las condiciones ambientales, por lo que, desde su definición, carece de perspectiva de desarrollo sustentable para las comunidades.

Para evaluar efectivamente el éxito de un proyecto de cuencas deben generarse indicadores en los tres ejes definidos en el concepto de desarrollo sustentable: económico, social y ambiental. No existe un consenso al respecto, a excepción de que la cuenca es la unidad de análisis, de gestión e intervención para diferentes fines, principalmente para el agua. Esto condiciona la formulación, ejecución, seguimiento y evaluación de las intervenciones.

El estudio de caso muestra que los indicadores generados desde una perspectiva de estado del sistema (características del espacio biofísico) y de la demanda de producción de bienes, permite la evaluación sistemática de parámetros a través de variables directas y percepciones del poblador.

El conjunto de escenarios al ser jerarquizado -en este caso bajo un sistema discreto- permite visualizar el comportamiento integral del sistema: evaluación desde la perspectiva de la entidad emisora del programa.

La herramienta aquí presentada permite llevar un eje de evaluación del programa, desde la planeación, implementación, valoración y continuidad-cierre, a través de indicadores multidimensionales, para que 
Garcés, J. A. (2011). Paradigmas del conocimiento y sistemas de gestión de los recursos hídricos: La gestión integrada de cuencas hidrográficas. Revista virtual REDESMA 5(1):29-41.

García, R. (2006). Sistemas complejos. Conceptos, método y fundamentación epistemológica de la investigación interdisciplinaria. Ed. Barcelona. 87 pp.

Gödel, K. (1986). Über formal unentscheidbare Sätze der Principia Mathematica und verwandter Systeme I. En: Kurt Gödel: Collected Works. Feferman, S. (ed.), volume 1. Oxford University Press. German text, parallel English translation. pp. 144-195.

Hilbert, D. (1904). On the foundations of logic and arithmetic Harvard Univ. 129-38.

Hilbert, D. (1927). The Foundations of Mathematics in van Heijenoort 1967:475

LULUCF. (2009). Information and Data on Land Use, Land-Use Change and Forestry (Septiembre de 2009). Canadá.

Luna, E. (2012). Metateoría: IR y los criterios científicos para elegir una teoría. Revista Vacío. Costa Rica Primer semestre. Ética de la gestión.

Munasinghe, M., \& Shearer, W. (1995). Defining and Measuring Sustainability-The Biogeophysical Foundations. Washington, DC. The United Nations University and The World Bank, ISBN 0-8213-3134-5

Muñoz, J. M. (2014). Totalidad y complejidad. Crítica de la ciencia reduccionista. UNAM. Centro de Investigación interdisciplinario en Ciencias y humanidades. 630 pp.

ONU. (2014). Indicators to Assess Watershed Health in British Columbia. Draft Discussion Paper. Discussion Paper Prepared by the Fraser Basin Council.

Pacheco, J. F., \& Contreras, E. (2008). Manual metodológico de evaluación multicriterio para programas y proyectos. Instituto Latinoamericano y del Caribe de Planificación Económica y Social (ILPES). Santiago de Chile, julio de 2008.

Payá, R. A. (2008). Estructura y Topología del Espacio Euclídeo. Universidad de Granada. Departamento de Análisis Matemático Facultad de Ciencias. Cap. 10, espacios de Hilbert. el personal encargado de su ejecución cuente con una herramienta de seguimiento y evaluación, y la comunidad receptora tenga una vía de calificación en cuanto a la eficiencia e impacto del programa.

La herramienta conceptual para lograr lo anterior son los espacios de Hilbert, que a su vez han sido operacionalizados por John Von Neumann y GramSchmidt. La construcción numérica desarrollada por estos autores es aplicable a la evaluación del manejo de cuencas de forma integral: en los tres ejes de desarrollo.

Fin de la versión en español

Ratcliffe, J., \& Stubbs, M. (1996). Urban planning and real estate development. University College London Gower Street. ISBN 0-203-2146-3 Master e-book

Rojas, J. H., y Pérez, M. A., Malheiros, T. F., Madera, C. A., Guimarães M., \& Dos Santos, R. (2013). Análisis comparativo de modelos e instrumentos de gestión integrada del recurso hídrico en Suramérica: los casos de Brasil y Colombia. Revista Ambiente \& Agua - An Interdisciplinary Journal of Applied Science 8(1):73-91.

Russell, R. J., Stoeger, W. R., \& Coyne, G. V. (2004). Física, filosofía y teología, una búsqueda en común. EDAMEX. $464 \mathrm{p}$.

Uribarri, I. Z. (2014). Crítica de la razón pura, de Immanuel Kant, en la traducción de José del Perojo (1883). Alicante: Biblioteca Virtual Miguel de Cervantes. Biblioteca de Traducciones Españolas. (Publicación en línea, disponible en internet en el sitio http://www. cervantesvirtual.com/nd/ark:/59851/bmcbc5t5 [con acceso el 12-3-2017]).

Velásquez, A. (2007). La organización, el sistema y su dinámica: una versión desde Niklas Luhmann. Revista Escuela de Administración de Negocios 61:129-156.

Villalpando, J. M. (2008). Manual moderno de lógica. Editorial Porrúa, México, D. F. 416 p.

Zela, A. (2013). Lógicas de primer y segundo orden. Cuadrantephi 26-27:1-15. 
